\title{
A cobertura da morte de figuras públicas na imprensa portuguesa
}

\author{
Joana Martins Mota \\ Instituto Politécnico de Viseu \\ E-mail: joanalopesmartinsegmail.com
}

\begin{abstract}
Resumo
A morte assume relevância do ponto de vista das narrativas mediáticas e, quando conjugada com a proeminência das personalidades envolvidas no acontecimento, confere maior peso à decisão do que pode ou não ser notícia. Neste trabalho propusemo-nos analisar a cobertura da morte de 20 personalidades públicas em três jornais diários portugueses: Correio da Manhã, Diário de Notícias e Jornal de Notícias. Escrutinámos o tratamento mediático que foi feito da morte de António de Oliveira Salazar, Fernando Pascoal das Neves, Francisco Sá Carneiro, Joaquim Agostinho, António Variações, José Afonso, Carlos Paião, Miguel Torga, Beatriz Costa, António de Spínola, Vítor Baptista, Amália Rodrigues,

Sophia de Mello Breyner, Álvaro Cunhal, José Megre, Raul Solnado, José Saramago, António Feio, Angélico Vieira e Eusébio da Silva Ferreira. Encontrámos tratamentos similares em alguns casos e coberturas diferenciadas em outros. Compreendemos que a morte enquanto disrupção e alteração no curso da vida é tanto mais mediatizada quanto maior foi o estatuto da personalidade que faleceu. Este estudo aponta não só no sentido da evolução das formas de tratamento dessa disrupção, como também invoca alguns mecanismos identificados nos jornais, concomitantes com a hiperconcorrência, a tendência para a espetacularização, a acentuação da tabloidização e com o fenómeno da pós-verdade.
\end{abstract}

Palavras-chave: morte; notoriedade; espetacularização; tabloidização; pós-verdade.

\begin{abstract}
Death assumes great relevance from the point of view of media narratives and, when combined with the prominence of the personalities involved, gives greater weight to the decision of what may or may not be news. We propose to analyze the coverage of the death of 20 public figures in three Portuguese daily newspapers: Correio da Manhã, Diário de Notícias and Jornal de Notícias. We have scrutinized the media treatment of the death of António de Oliveira Salazar, Fernando Pascoal das Neves, Fran-

cisco Sá Carneiro, Joaquim Agostinho, António Variações, José Afonso, Carlos Paião, Miguel Torga, Beatriz Costa, António de Spínola, Vítor Baptista, Amália Rodrigues, Sophia de Mello Breyner, Álvaro Cunhal, José Megre, Raul Solnado, José Saramago, António Feio, Angélico Vieira and Eusébio da Silva Ferreira. We found similar treatments in some cases and different coverages in others. We understand that death as disruption and change in the course of life is all the more mediatized the gre-
\end{abstract}

Data de submissão: 2017-10-29. Data de aprovação: 2017-12-04.

A Revista Estudos em Comunicação é financiada por Fundos FEDER através do Programa Operacional Factores de Competitividade - COMPETE e por Fundos Nacionais através da FCT - Fundação para a Ciência e a Tecnologia no âmbito do projeto Comunicação, Filosofia e Humanidades (LabCom.IFP) UID/CCI/00661/2013.

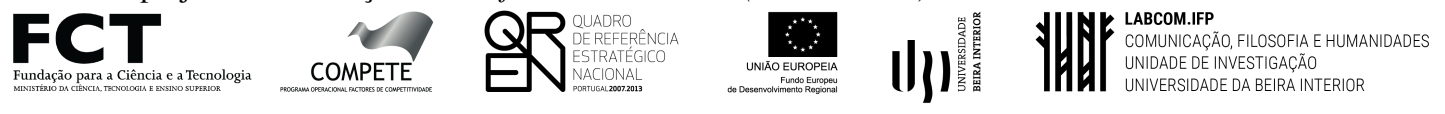


ater the status of the dead personality. This study not only points to the evolution of the ways of treating this disruption, but also invokes some mechanisms identified in the newspapers, concomitant with hyper-competition, the tendency towards spectacularization, the accentuation of tabloidization and post-truth.

\section{A morte: entre o tabu e a ubiquidade nos media}

A morte é um acontecimento disruptivo, mesmo quando, inelutável, é já esperada. A disrupção provocada pela morte pode ser avaliada pelos comportamentos dos sobreviventes, pelos cerimoniais e, ainda, pelos ritos a ela associados. Desde as contemporâneas cerimónias fúnebres do mundo ocidental, aos rituais de separação entre o corpo e a alma das pequenas comunidades, cada povo e cada território utiliza os seus próprios meios e procedimentos, as suas próprias cerimónias e ritos, para se despedir de quem parte, para assinalar essa partida e, em alguns casos, a sua entrada em outro mundo.

Até à Idade Média a morte foi um acontecimento tratado com alguma familiaridade, sendo também romantizada e, de certo modo, admirada pela sua beleza, uma atitude distante das manifestações de choro e dor identificadas a partir da Idade Moderna (Ariès, 2010, p. 48). Hoje em dia, porém, sabemos que existe um distanciamento em relação à morte, causado, na opinião de autores como Norbert Elias (1987), pela sua perceção como um tabu, devido ao facto de, na sua essência, ser algo desconhecido. Se durante a Idade Média, tal como explica Ariès (2010), os sinais de dor eram exuberantes, nas sociedades contemporâneas a morte é menos pública do que então e as manifestações de luto têm um carácter mais discreto. Este distanciamento está patente no facto de atualmente se morrer mais nos hospitais e menos em casa, na ideia de que é preciso utilizar eufemismos quando se aborda o tema com as crianças e ainda nas próprias cerimónias fúnebres, que visam ultrapassar rapidamente o processo de dor.

Paralelamente a esta atitude de afastamento em relação à morte e ao morto, a par com o seu cariz mais privado, deparamo-nos com uma quase omnipresença do fenómeno nos meios de comunicação social. À primeira vista estes dois posicionamentos podem parecer contraditórios, uma vez que as mesmas sociedades ocidentais que encaram a morte como um tabu lhe dedicam tanta atenção nas manchetes de periódicos e aberturas de telejornal. Ultrapassada esta primeira ideia de oposição entre as duas realidades, compreendemos que quando falamos em medo da morte ou na ideia de morte como um tabu, falamos de um receio assente no medo da nossa própria finitude, que subsiste lado a lado com uma curiosidade quase mórbida pela morte dos outros.

Keith Durkin (2003) foi um dos investigadores que tentou explicar esta dualidade de posicionamentos em relação à morte e concluiu, referindo-se à realidade norte-americana, que a negação da morte é aparente, pois na verdade a população está em contacto constante com ela, pela sua presença na cultura popular, por exemplo, em séries televisivas, no cinema ou na música. Ainda assim, Durkin admite a possibilidade de uma outra explicação para esta atitude contraditória, que pode residir no facto de a negação efetiva da morte ser compaginável com uma necessidade intrínseca de saber mais sobre ela. 
A dimensão negativa associada, em alguns casos, ao inesperado, dá à temática da morte nos media um elevado valor de noticiabilidade. No entanto, não basta que ela ocorra para que seja digna de notícia. A morte é um acontecimento comum, pelo que o efeito da sua noticiabilidade depende das condições da sua ocorrência. Em nosso entender, o caráter disruptivo da morte manifesta-se nas narrativas mediáticas, em particular, através de duas formas: do inesperado e da notoriedade. Sendo certo que o inesperado é um critério de noticiabilidade a ter em linha de conta, por vezes a morte esperada de uma personalidade de elevada notoriedade já é, por si só, garante de um tratamento mediático mais extenso. Foi a pensar nos diversos contextos de morte e dos próprio media, bem como nas mudanças inerentes ao sector da comunicação social, nos últimos 40 anos, que nos propusemos estudar a morte de 20 personalidades portuguesas falecidas nos últimos 47 anos. O objetivo desta análise foi o de analisar as narrativas mediáticas da morte de diferentes figuras públicas e a sua evolução ao longo do tempo. Tínhamos a certeza que a morte era um valor-notícia com bastante peso e estávamos também certos de que a notoriedade e o inesperado poderiam alavancar essa noticiabilidade. Por isso, ao analisar a presença da morte nas notícias procurámos estudar, em particular, o tratamento dos casos em que estão envolvidas figuras públicas. Combinámos, portanto, morte e notoriedade num só objeto de estudo, que nos propusemos clarificar analisando as páginas dos jornais que se seguiram à morte de 20 personalidades portuguesas.

\section{O estudo: discussão dos resultados}

Foi objetivo desta investigação perceber como se trilhou o caminho nas últimas quatro décadas no jornalismo impresso português, no que diz respeito ao tratamento da morte de figuras públicas. Para isso fizemos uma análise de três jornais diários de referência: o Diário de Notícias, o Jornal de Notícias e o Correio da Manhã. Esta investigação partiu, assim, de uma pergunta: como evoluiu o tratamento mediático da morte de figuras públicas, na imprensa escrita portuguesa, nos últimos 40 anos?

O estudo integrou várias personalidades que faleceram em idades diferentes e com distintos reconhecimentos públicos (algumas já consagradas, outras com um promissor futuro por cumprir) e considerando os segmentos mais representativos da sociedade do espetáculo (política, arte e desporto).

Optámos, nesta investigação, por uma análise quantitativa e por uma análise qualitativa do conteúdo das edições do Correio da Manhã, do Jornal de Notícias e do Diário de Notícias, no âmbito do tratamento noticioso que fizeram quando do falecimento de António de Oliveira Salazar, Fernando Pascoal das Neves (Pavão), Francisco Sá Carneiro, Joaquim Agostinho, António Variações, Zeca Afonso, Carlos Paião, Miguel Torga, Beatriz Costa, António de Spínola, Vítor Batista, Amália Rodrigues, Sophia de Mello Breyner, Álvaro Cunhal, José Megre, Raul Solnado, José Saramago, António Feio, Angélico Vieira e Eusébio da Silva Ferreira. O período temporal analisado foram os onze dias após a morte das figuras mencionadas e incluímos ainda na análise as edições do Correio da Manhã, do Diário de Notícias e do Jornal de Notícias das efemérides destas mortes: um mês, seis meses, um ano, dez anos e 20 anos. 
Na análise quantitativa contabilizámos o número de páginas de cada edição em que a personalidade foi referenciada, o número de peças publicadas e as imagens respeitantes a essas mesmas peças. Registámos, também, os destaques nas capas dos jornais e as fotografias existentes nessas primeiras páginas. Seguidamente procedemos à distinção dos géneros jornalísticos de cada uma das peças. Já no âmbito da análise qualitativa, retirámos dos textos informativos todas as marcas de subjetividade, desde adjetivos a excertos que mostravam proximidade ou um tom de pesar.

\section{Páginas, peças e géneros jornalísticos}

Após a análise foram encontradas 1226 páginas que referenciam a morte das 20 personalidades, nas 915 edições que integram o corpus. No que diz respeito às conclusões mais gerais do nosso estudo, percebemos que o Diário de Notícias foi o jornal que publicou o maior número de páginas, tendo referenciado as 20 figuras públicas em 544 das suas páginas (44\%). Segue-se o Jornal de Notícias, que ocupou 393 páginas (32\%) com os acontecimentos, e o Correio da Manhã, onde foram registadas 289 referências (24\%) às personalidades (Gráfico 1).

Gráfico 1 . Total de páginas em que foram referenciadas as 20 personalidades

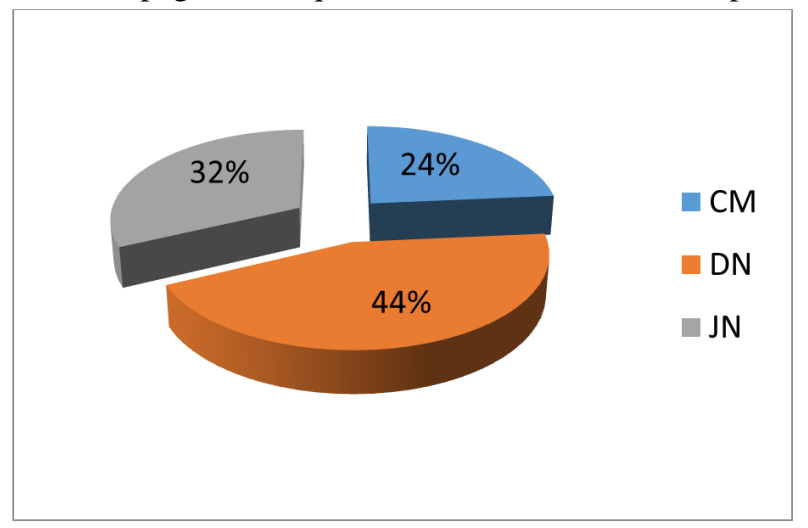

Fonte: Dados recolhidos na pesquisa.

Quisemos perceber quem foram as personalidades a que cada jornal dedicou mais atenção, a fim de traçar uma tendência editorial associada a cada um dos diários. Assim, das 20 personalidades que integram o estudo, 12 foram alvo de maior cobertura por parte do Diário de Notícias: Álvaro Cunhal, Amália Rodrigues, Oliveira Salazar, António de Spínola, António Variações (ex aqueo com o Correio da Manhã), Beatriz Costa, Eusébio, Joaquim Agostinho, José Megre, José Saramago, Sophia de Mello Breyner (ex aequo com o Jornal de Notícias) e José Afonso. O Correio da Manhã cobriu com maior extensão as mortes de Angélico Vieira, António Feio, António Variações, Carlos Paião, Raul Solnado e Vítor Baptista, figuras mais populares e consensuais, ainda que nos casos de António Variações e Vítor Baptista os percursos sejam um pouco mais fraturantes. $\mathrm{O}$ Jornal de Notícias destacou-se pela maior cobertura das mortes de Francisco Sá Carneiro, Miguel Torga, Pavão, Sophia de Mello Breyner e Vítor Baptista, a maioria dos quais com origem no Norte do país, tal como o próprio jornal. 
Face aos dados expressos no Gráfico 2, a primeira conclusão a retirar é que o Diário de Notícias confere maior atenção às figuras dos setores da política, das artes e do desporto estando, entre estes, as figuras de maior relevo público deste estudo (Amália, Eusébio, José Saramago, Oliveira Salazar e Álvaro Cunhal), numa tentativa que nos pareceu de se aproximar da interpretação do impacto da vida e obra de cada uma das personalidades na vida pública nacional.

Por sua vez, a linha que podemos traçar face às personalidades que mereceram mais atenção por parte do Correio da Manhã, coloca este diário próximo da cultura do espetáculo e das celebridades (Angélico, António Feio, António Variações, Carlos Paião e Raul Solnado). Estas são também figuras que se distinguem por serem personalidades consensuais e pouco fraturantes junto do público popular do jornal.

Quanto ao Jornal de Notícias, a linha que une as cinco personalidades a que este jornal deu maior atenção parece ser a geografia. Podemos levar em conta que a sua vocação como jornal nacional sediado no Norte do país se traduziu numa maior atenção aos casos de figuras públicas oriundas da zona de influência do jornal: do Porto para cima. Assim, Vítor Baptista é a única personalidade natural do sul do país.

Gráfico 2. Número de páginas ocupadas, por personalidade, em cada jornal

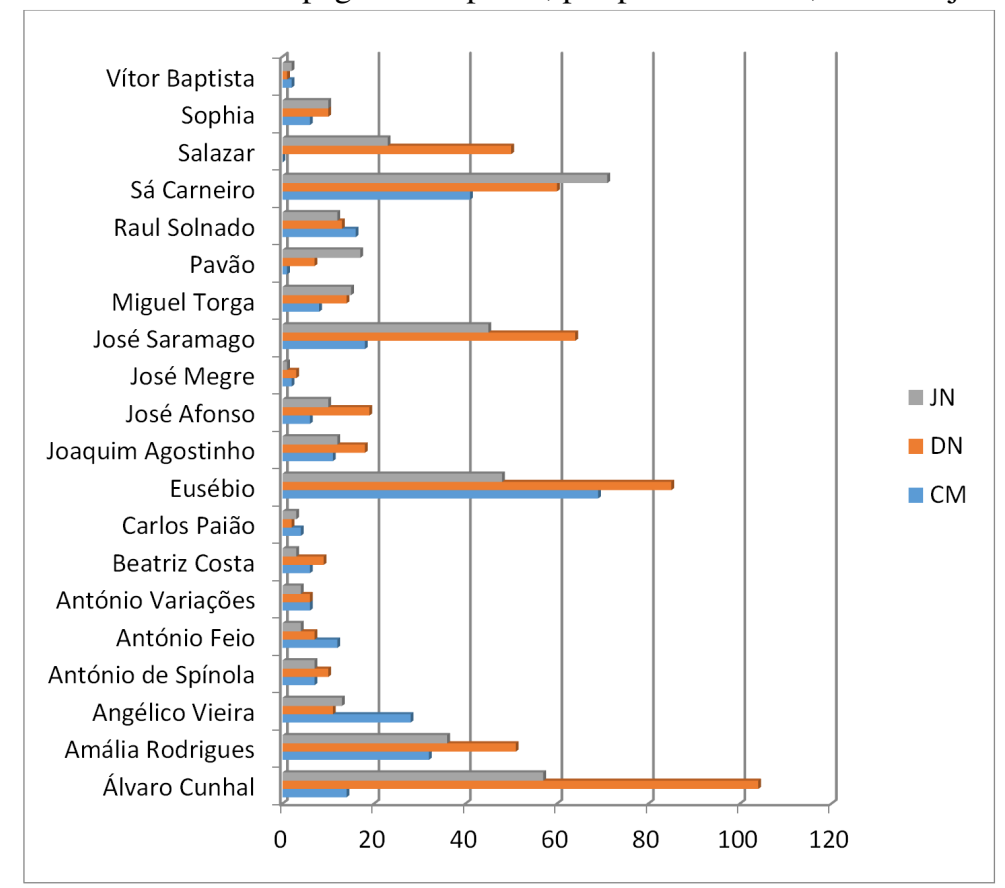

Fonte: Dados recolhidos na pesquisa.

Considerando apenas as personalidades, e o destaque que a morte de cada uma delas mereceu no conjunto dos três jornais, percebemos que a personalidade cuja morte foi mais mediatizada 
foi Eusébio, ocupando um total de 202 páginas. Segue-se Álvaro Cunhal, mencionado em 175 páginas dos periódicos e Sá Carneiro, em 172 edições.

Por outro lado, as personalidades cujas menções foram mais escassas são Vítor Baptista (cinco), José Megre (seis) e Carlos Paião (nove). No caso de José Megre, podemos compreender este menor grau de atenção pelo facto de a personalidade ser uma referência numa modalidade (automobilismo) cuja atenção mediática é menor. Quanto a Vítor Baptista, trata-se de uma figura afastada do mediatismo há cerca de 20 anos, pelo que a tendência de esquecer quem não está presente pode explicar a pouca cobertura da sua morte, ainda que durante a vida ativa o jogador tenha sido uma estrela do futebol. No entanto, poderíamos argumentar que também Eusébio esteve longe dos campos de futebol e, neste estudo, foi a personalidade cuja morte teve mais destaque. No caso de Vítor Baptista o que poderá estar em causa são as circunstâncias da sua vida, uma vez que apesar de ter sido um jogador da equipa principal do Sport Lisboa e Benfica, morreu na miséria, após um passado relacionado com drogas. Carlos Paião, por sua vez, pode ter tido uma morte menos mediatizada pelo facto de o acidente que o vitimou ter acontecido um dia após o incêndio do Chiado, em pleno mês de agosto, quando as redações se encontram mais desfalcadas em termos de recursos humanos, tendo direcionado os meios existentes para a cobertura do incêndio ocorrido no centro da cidade de Lisboa. Ainda assim, a pouca informação veiculada poderia ter sido compensada, por exemplo, com maior destaque alguns dias depois, algo que não sucedeu e que procuraremos explicar quando abordarmos o ruído em torno destes eventos.

Procurámos também aferir acerca das mortes com maior e menor taxa de cobertura no conjunto dos três jornais, no total dos onze dias após a morte e respetivas efemérides. O maior número de peças foi escrito por referência a Eusébio (420), seguindo-se Francisco Sá Carneiro (345) e Oliveira Salazar (277). Também aqui, o menor número de artigos escritos refere-se aos falecimentos de Vítor Baptista (cinco), José Megre (seis) e Carlos Paião (sete).

Os géneros jornalísticos foram um dos parâmetros incluídos neste estudo. Neste campo, a primeira conclusão a retirar (Gráfico 3) é que as breves são o género mais presente na análise e representam $29 \%$ do total de peças. As notícias foram o segundo género mais utilizado (26\%) e em terceiro lugar aparecem os artigos de opinião (12\%). 
Gráfico 3. Número total de peças, por género jornalístico, nos três jornais

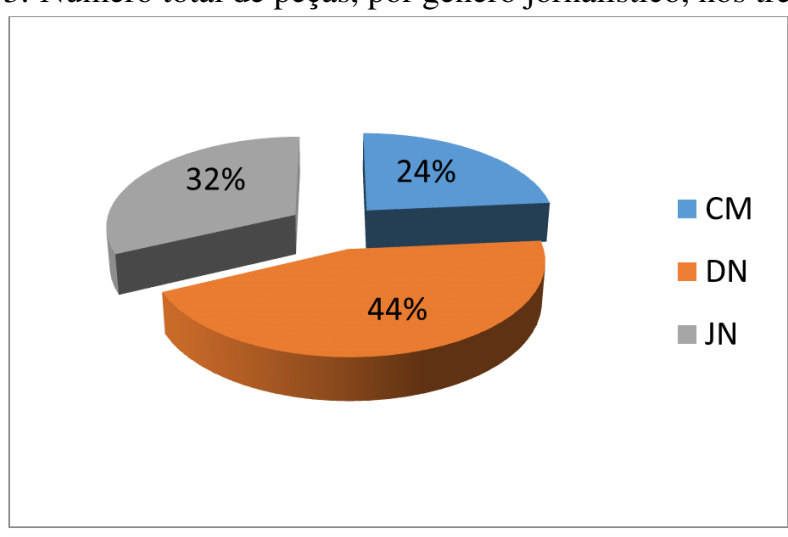

Fonte: Dados recolhidos na pesquisa.

Uma das conclusões que retirámos da análise prende-se com o facto de a biografia ser um género sempre presente quando é noticiada a morte de uma personalidade e de ela aparecer, sobretudo, no dia a seguir ao falecimento. A presença da biografia é, antes de mais, uma forma de recordar a importância que a personalidade assumiu durante a sua vida e exaltar os feitos que conquistou, os quais fazem parte da narrativa que tornou a figura pública numa celebridade. Se, como defende Gabler (2001, p. 5), a existência de uma narrativa é condição sine qua non para a constituição de uma celebridade, o nosso estudo revela que faz sentido que analisemos a biografia como um dos géneros onde essa narrativa mais se evidencia. Assim, a presença da biografia é um claro sinal da necessidade de fazer o balanço do que a personalidade alcançou em vida, uma espécie de juízo final que cimenta a posição daquela figura e ajuda a legitimar o espaço que o jornal lhe consagra aquando da sua morte. Ariès (2010, pp. 36-38), quando fala sobre a história da morte no ocidente identifica como elemento de mudança nas atitudes perante a morte, entre a baixa e a alta Idade Média, a representação do que acontecia no quarto do moribundo. O historiador relata que muita da iconografia mostra uma espécie de balanço de vida do moribundo, como se, momentos antes da sua morte, o indivíduo se visse perante todo o seu passado, numa espécie de síntese entre o que fez de bom e o que fez e mau. A presença da biografia nos jornais relaciona-se com esta noção de juízo final, que se prende na ideia de sintetizar uma vida que chega ao seu fim físico. Ora, no caso das figuras públicas, os feitos são também públicos, pelo que cumpre ao periódico recordá-los, construindo uma narrativa, equivalente à "biografia da vida particular" que, na transição da Idade Média, Ariès (2010, p. 37) concluiu que era feita para os moribundos. No caso das figuras públicas, estamos perante uma biografia da vida pública, que se torna pertinente recordar após a sua morte, ou nos momentos de co-memoração desse evento.

Ainda no que diz respeito aos géneros jornalísticos, concluímos que as reportagens são o recurso para fazer a cobertura das cerimónias fúnebres e que as breves são utilizadas na descrição dessas mesmas exéquias para isolar pormenores ou eventos paralelos ao acontecimento.

Ainda a destacar a proliferação de géneros menos habituais noutras coberturas jornalísticas, como as cronologias, que complementam as biografias, constituindo-se quase como uma segunda 
biografia, na tarefa de marcar os momentos mais importantes do percurso da figura pública. Por sua vez, as vozes, não sendo um género jornalístico, são representativas de $7 \%$ do total de peças. Estas servem, essencialmente, para ouvir outras personalidades sobre o desaparecimento de determinada figura pública. Para efeitos deste estudo, considerámos a existência de uma unidade de vozes sempre que as citações das personalidades ouvidas fossem contidas na mesma caixa ou coluna, encimadas pelo mesmo cabeçalho. No entanto, uma unidade de vozes contém, em todos os casos, várias personalidades que dão o seu testemunho sobre a figura pública falecida. É relevante assinalar a primazia deste género jornalístico, porque os jornais mostraram uma tendência para o utilizar, sempre que alguém morre, apesar de os restantes textos jornalísticos também integrarem reações e depoimentos de personalidades ouvidas no âmbito da morte da figura. Parece-nos, pois, que existe uma tendência para isolar num espaço próprio da página as reações e/ou depoimentos das personalidades ouvidas pelo jornal, como forma de lhes atribuir uma importância singular, algo que se assume como uma tendência a partir dos anos 90, pois nos casos analisados referentes às décadas de 70 e 80 não era comum verificar-se esta situação. Concomitantemente, o facto de estas vozes se constituírem num género próprio, tendencialmente paginadas autonomamente, ajuda a consolidar a importância da personalidade falecida: quanto mais importante for a figura pública, maior o grau de importância das vozes ouvidas e maior o número de pessoas que se manifesta nestas vozes.

No que toca às vozes, há a tendência de ouvir o Presidente da República e o primeiro-ministro ou um membro do governo. Muitas vezes notamos, ainda, que o ministro com a pasta da área de atividade em que a personalidade falecida se notabilizou faz parte da lista de pessoas a ouvir. Por outro lado, há casos, como o do cantor Angélico Vieira, em que as vozes são exclusivamente de colegas e amigos da personalidade, sendo a representatividade do Estado totalmente nula, uma vez que nenhum membro ou representante oficial do Governo ou do Estado é ouvido por nenhum dos jornais.

Optámos, pois, por discriminar os casos em que os dois mais altos representantes políticos são ouvidos pelos jornais. Os únicos casos em que todos os jornais analisados ouviram os dois principais representantes da nação foram os de Amália Rodrigues, Oliveira Salazar, António de Spínola, Eusébio ou José Saramago. De realçar que, quando da morte de Sá Carneiro, todos os jornais publicaram a reação do Presidente da República, mas aqui estávamos perante a terceira figura mais importante do Estado, que tinha acabado de falecer.

Os casos que não tiveram qualquer mensagem de condolências publicada nos jornais analisados por parte das principais figuras políticas do país dizem respeito às mortes de Angélico Vieira, António Variações, José Megre, Pavão e Vítor Baptista.

No caso de Sophia de Mello Breyner, por exemplo, o Correio da Manhã e o Diário de Notícias publicam a reação de Jorge Sampaio, mas não de António Guterres. Em vez do primeiro-ministro, é colocada a reação do ministro da Cultura, Pedro Roseta. António Guterres surge, no entanto, citado em declarações prestadas ao Jornal de Notícias. 


\section{As imagens}

Das 2280 imagens identificadas no conjunto dos 20 casos escolhidos para este estudo (Gráfico 4), Eusébio foi a personalidade cujo conteúdo representa maior número de fotografias utilizadas. Assim, 20\% do total de imagens foram publicadas nos jornais referentes a Eusébio. Em segundo lugar, encontramos Álvaro Cunhal, cuja cobertura da morte originou a publicação de 259 imagens. Segue-se Sá Carneiro (245 imagens), José Saramago (238 imagens) e Amália Rodrigues (206 imagens). Em sentido contrário estão as personalidades cuja morte foi alvo de menos atenção por parte dos periódicos: Vítor Baptista, José Megre e Carlos Paião.

Gráfico 4. Número de imagens utilizadas na cobertura da morte das personalidades nos jornais

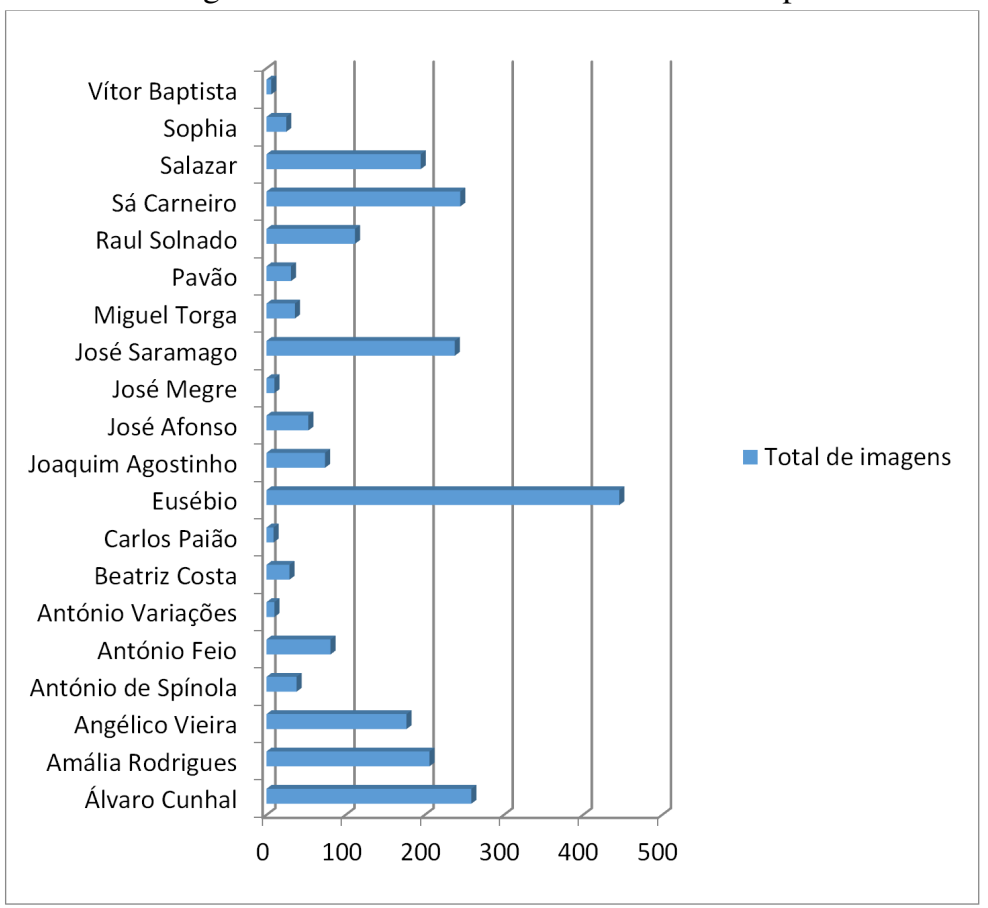

Fonte: Dados recolhidos na pesquisa.

No âmbito do uso das imagens, outro aspeto que nos parece relevante prende-se com os casos em que essas mesmas imagens retratam os cadáveres das personalidades.

Autores como Folker Hanusch (2010) ou Barbie Zelizer (2010) argumentam que as imagens da morte nas notícias não são gráficas e procuram, até, esconder a morte. A realidade é que nem todas as personalidades levaram os jornais a publicar as suas imagens dentro do caixão. Em alguns casos isso deveu-se ao facto de o jornal não acompanhar o funeral da personalidade ou, até, de o funeral ter acontecido com o caixão fechado.

No total foram publicadas 37 fotografias dos corpos, sendo que destas 17 foram dadas à estampa pelo Jornal de Notícias, enquanto o Correio da Manhã e o Diário de Notícias publicaram dez imagens cada. 
As 37 imagens de cadáveres em que se vê a presença do cadáver (Gráfico 5) dizem respeito a Salazar (nove), Eusébio (sete), Amália Rodrigues (seis), Joaquim Agostinho (cinco), António de Spínola (três), José Saramago (três), Pavão (três) e José Afonso (uma). Apesar de neste caso só terem sido analisados dois jornais (Diário de Notícias e Jornal de Notícias), Salazar é a personalidade mais vezes representada após a morte.

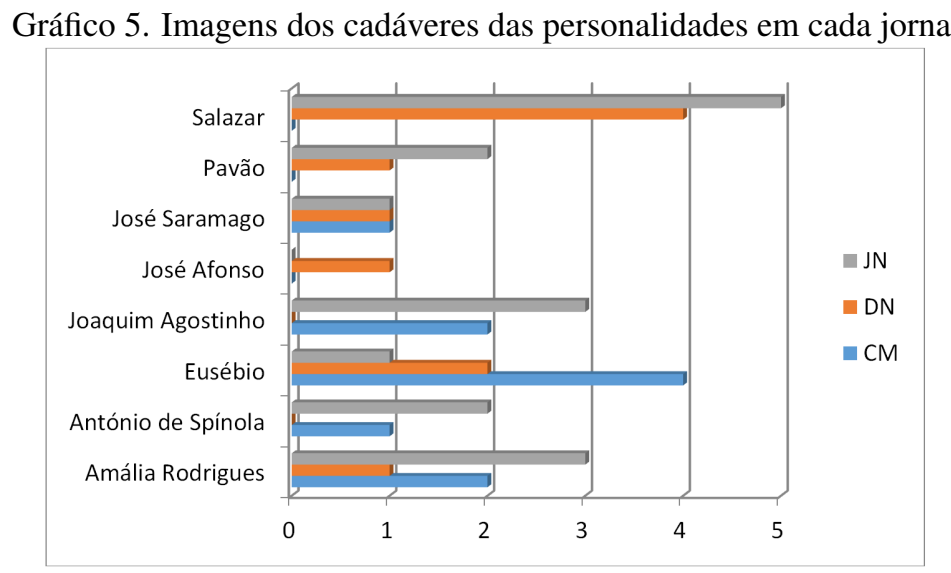

Fonte: Dados recolhidos na pesquisa.

No total temos 37 imagens dos cadáveres das personalidades, o que representa 4,83\% do total de fotografias publicadas junto dos artigos que fizeram referência à figura pública na sequência da sua morte. Parece-nos importante recordar aqui o estudo levado a cabo por Hanusch (2008, p. 315), que após analisar quatro jornais concluiu que das 351 imagens encontradas, só 16 eram fotografias onde era possível ver o corpo da pessoa falecida, ou seja, $4,56 \%$.

De acordo com a perspetiva de Hanusch (2010, p. 77), hoje em dia são pouco frequentes as imagens da morte na imprensa. Indo ao encontro desta teoria, concluímos que as imagens mais antigas são mais gráficas do que as atuais, no sentido em que a maioria dos cadáveres retratados figura em jornais com, pelo menos, 20 anos: António de Spínola, José Afonso, Joaquim Agostinho, Pavão e Salazar. À medida que avançamos no tempo, os jornais parecem retrair-se e inibir-se de mostrar o corpo da personalidade, exceto em casos de personalidades que se distinguem pela sua notoriedade, como Amália, José Saramago ou Eusébio.

Aquando da morte de Joaquim Agostinho, em 1984, todos os jornais analisados mostraram, sem qualquer pudor, o corpo do ciclista exposto no caixão. Neste caso concreto, falamos de uma morte na sequência de um acidente do qual resultou uma fratura no crânio, pelo que a cabeça de Agostinho estava envolta em ligaduras, o que não inibiu os jornais de o retratarem de perto. Não podemos deixar de mencionar o ângulo mais tímido que os jornais adotaram a partir de 1999. No caso de Amália Rodrigues, por exemplo, os três jornais escolheram ângulos, ora panorâmicos, ora distanciados, de modo a não expor demasiado a imagem do cadáver ao leitor. No caso de José Saramago, o Correio da Manhã foi mais desinibido, mas o Diário de Notícias e o Jornal de Notícias optaram por uma fotografia que desfoca o rosto do morto. Já no que diz respeito a Eusébio, os 
jornais não hesitaram em mostrar o cadáver de uma forma mais aberta do que nos outros casos, pondo fim ao que parecia ser um posicionamento de maior contenção.

Ainda que ao longo dos anos continuasse a ser mostrada a morte, os jornais passaram a fazêlo, na maioria das vezes, recorrendo a uma simbologia (as flores ou o caixão fechado), de modo a esconder o corpo, possivelmente numa atitude de retração e respeito. Não queremos com isto dizer que os jornais não respeitem Amália, José Saramago ou Eusébio, nem sequer que não tenham respeitado as figuras que retrataram de caixão aberto durante os anos 80 e parte dos anos 90 . Apenas salientamos a emergência de uma política da imagem, sustentada na bibliografia consultada, acerca da morte, a que, aparentemente, só as grandes figuras parecem escapar.

\section{Primeiras páginas}

Outro dos aspetos que nos pareceu pertinente isolar e analisar é a presença das personalidades, após a sua morte, nas capas dos jornais analisados. Registámos 155 destaques de primeiras páginas, no total das 915 edições analisadas, sendo que a maioria são referentes ao Diário de Notícias (60), seguindo-se o Jornal de Notícias (55) e o Correio da Manhã (40).

Quanto ao tipo de destaques, aquele a que os jornais recorreram mais vezes foi a chamada, seguida da foto de capa, da manchete e da capa inteira. Registámos apenas dez referências nos 155 destaques identificados.

Francisco Sá Carneiro, Eusébio, Amália, Salazar e Álvaro Cunhal foram as cinco personalidades cuja morte foi mais destacada nas capas dos jornais (Gráfico 6). Em relação a Sá Carneiro é preciso recordar que o então primeiro-ministro morreu num acidente de viação em véspera de eleições presidenciais, pelo que, além da relevância da sua morte, que justificou alguns dos destaques de primeiras páginas, é preciso ter em conta que muitas vezes o seu nome surgiu também no contexto das notícias acerca da situação de incerteza política que a sua morte gerou, dada a proximidade das eleições presidenciais. Já no que toca a Salazar, o facto de o ex-Presidente do Conselho se encontrar em quarto lugar (sobretudo tendo em conta que só dois jornais foram analisados) não é imune à vigência do Estado Novo e a uma certa deferência, sobretudo por parte do Diário de Notícias, identificado como jornal oficioso do regime. A questão da censura não só cortava excertos dos textos, como também obrigava os jornais a publicar informações, pelo que a presença da morte de Salazar nas capas dos jornais não pode ser olhada de forma isolada dessa realidade.

O destaque das capas no que toca às restantes personalidades é mais ou menos equivalente. No entanto, parece-nos relevante elencar as personalidades cuja morte não fez parte das primeiras páginas dos jornais analisados. O falecimento de José Megre e Vítor Baptista não figurou em nenhuma das capas dos três diários. Ainda de referir o caso de José Afonso, que não foi referenciado em nenhuma primeira página do Correio da Manhã, sendo que motivou um total de quatro referências nas primeiras páginas do Diário de Notícias e do Jornal de Notícias. 
Gráfico 6. Destaques de primeira página, para cada personalidade, nos três jornais

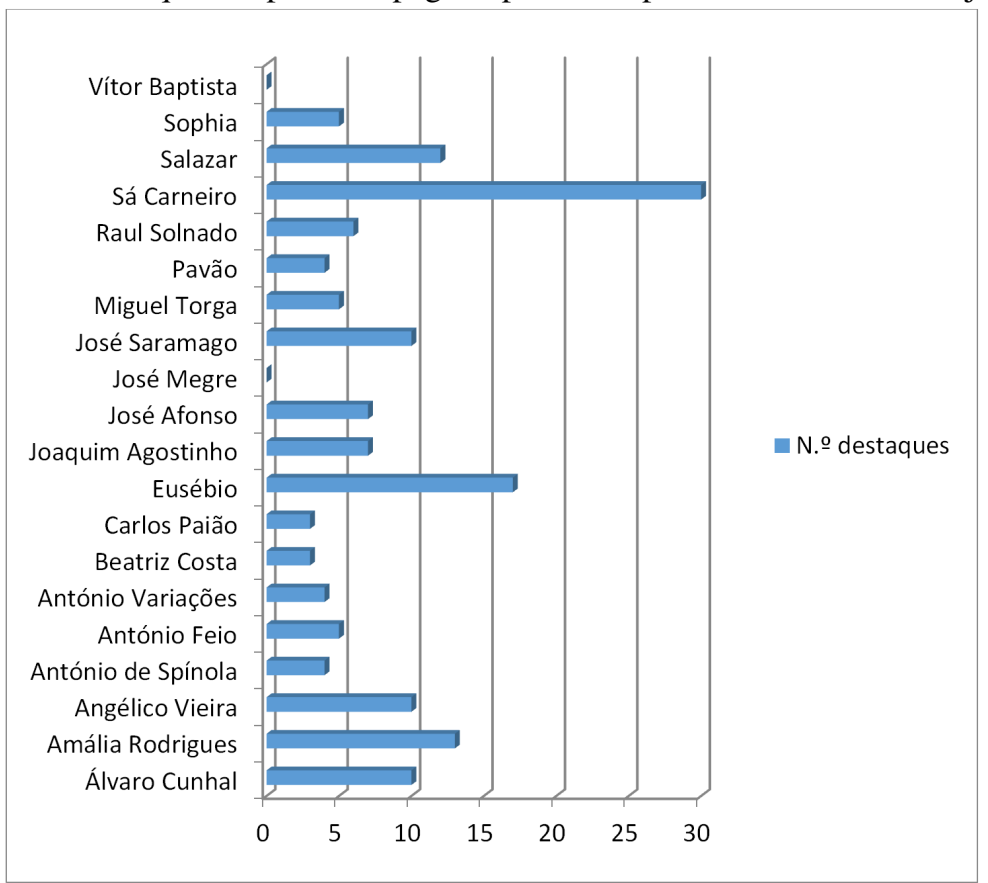

Fonte: Dados recolhidos na pesquisa.

As primeiras páginas comportam, muitas vezes, títulos e opções gráficas que se afiguram como sinónimo de empenho e mobilização e que, por vezes, podem ser interpretados como verdadeiros epitáfios. Ao longo do nosso estudo encontrámos alguns exemplos que mostram uma certa construção da memória coletiva, por parte do jornal, ao escolher frases que visam homenagear a personalidade falecida ou, ao contrário, optar pela economia das palavras, em jeito de recolhimento.

O primeiro exemplo foi encontrado após a morte de Amália Rodrigues. Até então os jornais, na maioria das vezes, fazem os seus títulos anunciando que morreu determinada personalidade, podendo então atribuir-lhe caraterísticas, como no caso de Spínola, quando o Diário de Notícias escreve que "Morreu o símbolo da transição" (Diário de Notícias, 1996) ou de Beatriz Costa, quando se lê "Beatriz Costa - Morreu a menina de Lisboa" no Jornal de Notícias (Jornal de Notícias, 1996). No dia após o falecimento de Amália Rodrigues, o Diário de Notícias preencheu a primeira página com uma fotografia da fadista e, em baixo, uma pequena legenda, onde se dizia apenas "Amália, quis Deus que fosse o meu nome" (Diário de Notícias, 1999), deixando transparecer a intenção do jornal em deixar a imagem falar por si. O mesmo jornal foi mais longe após a morte de Álvaro Cunhal, visto que no dia seguinte publicou apenas uma imagem a preto e branco do ex-líder comunista, que ocupava a totalidade da capa, e sem qualquer título, legenda ou menção. Por baixo lê-se apenas "Reedição actualizada do especial DNa dedicado a Álvaro Cunhal" (Diário de Notícias, 2005). 
Outro exemplo acontece a propósito da morte de Sophia de Mello Breyner. No dia seguinte, o Diário de Notícias escreve apenas "Sophia 1919-2004" em cima de uma imagem, a preto e branco, da poetisa (Diário de Notícias, 2004). Álvaro Cunhal é outro dos casos onde se registam estratégias semelhantes, com o Correio da Manhã a colocar também a data de nascimento e de morte junto da sua imagem (Correio da Manhã, 2005). O mesmo acontece no Diário de Notícias, após a morte de Eusébio (Diário de Notícias, 2014).

Com a morte de Álvaro Cunhal, o Jornal de Notícias opta por outra estratégia, publicando a fotografia do ex-dirigente do PCP e, ao lado, o título "tudo o que faz o verão subir a prumo chegou ao fim", citação de Eugénio de Andrade, numa alusão à morte de ambos que aconteceu no mesmo dia (Jornal de Notícias, 2005). Raul Solnado é também exemplo destes títulos em formato de epitáfio. Podemos salientar a opção do Jornal de Notícias que, usando uma imagem do ator na sua juventude, adaptou uma conhecida frase sua e titulou: "Faz o favor de ser feliz" (Jornal de Notícias, 2009). Exemplo semelhante, também no Jornal de Notícias, foi identificado após a morte de José Saramago, quando o periódico, em mais de meia página, por cima da imagem da personalidade, coloca entre aspas o título "A história acabou, não haverá mais nada que contar", uma citação do livro Caim, da autoria do escritor (Jornal de Notícias, 2010).

\section{O papel das efemérides e o cabide noticioso}

Com a análise das efemérides do falecimento das pessoas públicas, quisemos perceber o processo e o papel dos jornais na inscrição da memória pública, procurando assim verificar se e como eram recordadas as datas comemorativas da morte das personalidades em estudo. Por isso, incluímos a efeméride de um mês, pela proximidade à data da morte, seis meses, que se revelou inexistente, um, dez e vinte anos. A esta temporalidade esteve também subjacente a ideia de cabide noticioso, conceito assente no tempo cíclico e na memória, e um dos valores-notícia de seleção elencados por Nelson Traquina (2002). De acordo com este autor, o tempo pode ser pretexto para determinadas notícias, como é o caso dos aniversários.

A propósito das visitas periódicas aos cemitérios, Fernando Catroga (1999, p. 22) destaca a importância da recordação como forma de ressuscitar acontecimentos do passado, sobretudo quando falamos de aniversários coletivos (Dia de Todos os Santos) ou individuais. No caso das efemérides das personalidades que fizeram parte deste estudo, percebemos que, tal como diz Catroga, muitas vezes a comemoração da data, além de recordar a pessoa, visa também reintroduzir o acontecimento na vida presente e nas expetativas de futuro, em consonância também com a ideia de cabide noticioso.

Encontrámos eco desta ideia nas efemérides do primeiro ano após a morte de Francisco Sá Carneiro, em que o Diário de Notícias aproveita para recordar que a origem do acidente ainda não foi esclarecida.

Há casos em que a efeméride não existe com esse propósito e não há uma estratégia do jornal para recordar a personalidade falecida. Em alguns desses casos a personalidade e a sua morte são o cabide noticioso de outro acontecimento. Por exemplo, no dia em que se completaram dez anos da morte de Sophia de Mello Breyner Andresen os jornais publicaram uma peça sobre a trasladação do corpo da poetisa para o Panteão Nacional, que teria lugar nesse mesmo dia. O foco das notícias 
foi a transferência dos restos mortais da escritora e nenhum dos jornais aproveitou a ocasião para recordar o seu trajeto. Nestes casos não é o jornal que traz à memória do público alguém que já faleceu. É a própria realidade que se impõe ao jornal, que, por sua vez, pode nem evocar a personalidade, mas sim centrar-se nos factos que ajudaram a trazê-la à lembrança. $\mathrm{O}$ facto de os restos mortais de Sophia serem trasladados para o Panteão Nacional marcaram a agenda noticiosa do $10{ }^{\circ}$ aniversário da sua morte, pelo que a memória dos media é diferida por um acontecimento externo que condiciona as suas escolhas.

Exemplo disto mesmo são os seis meses após a morte de Francisco Sá Carneiro. Coincidentemente, na véspera, os filhos do primeiro-ministro falecido haviam recusado a condecoração que seria atribuída ao pai. Assim, as notícias surgem na edição daquele dia, mas nenhuma evoca os seis meses decorridos sobre a morte de Sá Carneiro.

Quando da primeira década após a morte de Francisco Sá Carneiro, havia sido inaugurada, na véspera, a nova aerogare no Porto, à qual foi dado o nome do ex-primeiro-ministro. Esta inauguração deu o mote para a efeméride. Se, por exemplo, o Correio da Manhã não aproveita o acontecimento para recordar o político, o Diário de Notícias relega a inauguração para segundo plano e foca o seu conteúdo noticioso na evocação da personalidade, enquadrando novamente a falta de conclusões em torno do acidente que vitimou Sá Carneiro. Também o programa de homenagens dedicado a Miguel Torga, e anunciado aquando dos dez anos sobre a sua morte, justificam grande parte dos conteúdos escritos pelo Diário e Notícias e Jornal de Notícias, ainda que os dois diários aproveitem para recordar o escritor. O primeiro ano após a morte de José Saramago também foi ancorado nas homenagens que visavam assinalar a data. $\mathrm{O}$ mesmo se verifica nos 20 anos após a morte de António Variações: a propósito da intenção da EMI-Valentim de Carvalho em lançar um álbum de homenagem ao cantor, o Correio da Manhã aproveita para fazer a sua biografia e fala na doença que o vitimou, a Sida, que, diz o jornal, à data "ainda era considerada a praga dos homossexuais" (Fidalgo, 2004).

Ainda de destacar os 20 anos após a morte de José Afonso. Apesar de estarem agendadas iniciativas para esse dia, nenhum dos jornais colocou o enfoque nessas homenagens. Curiosamente o ângulo foi o mesmo nos três diários: o olhar sobre os músicos das novas gerações e o legado que José Afonso representava para cada um deles. É um exemplo de como a efeméride pode ser explorada e amplificada, tendo por base não a memória diferida por um qualquer cabide noticioso oficial, mas pela agenda autónoma dos media, que julga a efeméride como um facto suficiente para se constituir como notícia. A exposição inaugurada aquando dos dez anos da morte de Amália Rodrigues também deu o mote para que os três jornais recordassem a fadista, mas todos foram mais longe e abriram a amplitude do tema, evocando a cantora e convocando articulistas para a recordarem. O facto, aliás, de o acontecimento ser foto de capa no Jornal de Notícias explica bem a relevância de Amália, mesmo dez anos após a sua morte.

As verdadeiras efemérides mediáticas serão, então, aquelas que não utilizam qualquer cabide noticioso e simplesmente evocam a personalidade, tendo por base uma opção editorial e não outros agendamentos exteriores. É o que acontece nos dez anos e nos vinte anos após o falecimento de Joaquim Agostinho, em que o Correio da Manhã, o Diário de Notícias e o Jornal de Notícias recordam o ciclista, a sua carreira e as circunstâncias da sua morte. O mesmo se verifica no primeiro aniversário da morte de Carlos Paião, por parte do Correio da Manhã, e no primeiro 
ano após o falecimento de Amália Rodrigues no Correio da Manhã, Diário de Notícias e Jornal de Notícias. O mesmo se pode dizer da morte de Álvaro Cunhal, pois na passagem da primeira década sobre o acontecimento, o histórico líder comunista motivou a foto de capa do Diário de Notícias e uma entrevista de quatro páginas a Pacheco Pereira, seu biógrafo, sem nenhum acontecimento externo que motivasse a memória do jornal.

\section{A questão do ruído}

Outra das conclusões que podemos retirar da análise efetuada neste estudo prende-se com o ruído que diminui o grau de atenção que algumas das mortes aqui estudadas tiveram por parte dos periódicos. Definimos ruído, porque se tratam de factos que perturbam a atenção dada ao falecimento de cada uma das personalidades. Mas podemos chamar-lhes também acontecimentos concorrentes, que disputam a atualidade em cada uma das edições. Com efeito, muitas vezes este ruído está diretamente ligado com os valores-notícia que assumem maior primazia em relação a outros de menor importância. Além disso, a questão do ruído determina o poder e a autonomia das personalidades de se imporem aos media e aos acontecimentos.

O incêndio no Chiado, um dia antes da morte de Carlos Paião, é um exemplo concreto de como a morte do cantor, sobretudo dadas as suas circunstâncias trágicas ${ }^{1}$, foi menos desenvolvida do que, presumivelmente, teria sido se o incêndio não tivesse ocorrido no dia anterior. Sobressai a ideia que os periódicos estavam demasiado centrados no incêndio e nas suas consequências, para poderem prestar a devida atenção à morte prematura de Paião. Soma-se a isto o facto de Paião ter falecido a 26 de agosto, que coincide com um período em que habitualmente as redações têm menos jornalistas. A cobertura da morte de Angélico Vieira, cujo falecimento se deu mais ou menos nas mesmas condições, poderia levar-nos a projetar uma cobertura similar em relação à morte de Carlos Paião, algo que não se verificou. Não desvalorizando a temporalidade de cada um dos acontecimentos e as mutações verificadas na noticiabilidade dos media, a explicação mais imediata para este tipo de disparidade prende-se com o impacte noticioso de um acontecimento como o incêndio do Chiado. Segundo Traquina (2002, p. 197), o dia noticioso significa que os acontecimentos do dia estão em concorrência uns com os outros, pelo que um acontecimento como o incêndio no Chiado, tendencialmente, impor-se-á a todos os restantes.

No entanto, e visto que incluímos onze edições pós-morte de cada personalidade, alguns dias depois, feito o rescaldo noticioso do incêndio, os periódicos poderiam ter recuperado a notícia da morte de Paião, algo que não aconteceu. Com isto fica provado que, por razões de coerência editorial, quando um acontecimento perde a sua oportunidade de ser noticiado, pode nunca mais recuperar dessa situação. No caso da morte de Paião, a sua secundarização prende-se, diretamente, com a particularidade do dia noticioso, mas, também, com a autonomia da personalidade. Se, em vez de Carlos Paião, o trágico acidente tivesse ocorrido com Amália, os jornais não deixariam de fazer uma cobertura massiva do acontecimento, não obstante o incêndio do Chiado. Com efeito, não são apenas os media que atribuem mais ou menos relevância às personalidades

1. Carlos Paião morreu no dia 26 de Agosto de 1988, com apenas 30 anos, a caminho de um espetáculo em Penalva do Castelo. O carro onde seguia embateu num camião que seguia em sentido contrário, causando a morte de mais um ocupante da viatura. 
públicas. Quanto menos o reconhecimento público de uma personalidade estiver dependente dos media, maior a sua capacidade de ela se impor às contingências noticiosas do dia. Deste modo, não será possível pensar os acontecimentos mediáticos como uma pura produção dos meios de comunicação social: por vezes, o tratamento mediático está para além dos media e é-lhes socialmente imposto.

Também a final do Campeonato da Europa de Futebol, na qual Portugal defrontou a Grécia, no dia do funeral de Sophia de Mello Breyner, pode ter alterado o destaque dado à cobertura noticiosa do falecimento da poetisa. A sua morte foi noticiada e teve algum destaque nas primeiras páginas dos três jornais analisados. No entanto, o seu funeral acabou por não merecer qualquer destaque de primeira página, nem pelo Correio da Manhã, nem pelo Jornal de Notícias, tendo o destaque ido para a Seleção Nacional, que, na véspera, havia perdido, frente à Grécia, a final do Campeonato Europeu de futebol, tema que ocupou em exclusivo as primeiras páginas destes jornais. Neste âmbito, o Diário de Notícias foi o único a dar algum espaço ao funeral de Sophia, com uma chamada de primeira página sobre o acontecimento.

O ruído que afeta a noticiabilidade revela-se também no caráter excêntrico de António Variações e, na altura, da doença que o matou. De facto, a morte de António Variações foi um dos acontecimentos analisados com menos destaque nos jornais, apesar de gozar já de algum reconhecimento na sua vida pública e artística. Neste caso, seria de esperar que a morte de um jovem cantor desse que falar, sobretudo por ter falecido de uma doença ainda desconhecida. Paradoxalmente, parece-nos que talvez seja essa uma das justificações para o menor grau de atenção mediática que António Variações obteve. O músico foi uma das primeiras vítimas conhecidas de Sida, em Portugal e, face à estranheza e à complexidade que a doença ainda causava na altura, em alguns casos estigmatizada socialmente, talvez os jornais tivessem optado por secundarizar o falecimento de António Variações. A acrescentar a este facto, também a irreverência de António Variações e a estranheza que a sua imagem causava poderão também justificar o afastamento que os jornais assumiram aquando da sua morte.

No caso de António Variações, o Correio da Manhã foi o único jornal que usou a palavra Sida, mas em forma de interrogação: "a pneumonia surge como a hipótese mais consistente para justificar a morte de Variações, embora se avente também a probabilidade de o cantor minhoto ter sido vítima de um invulgar síndrome pulmunar. A SIDA?” [sic] (Correio da Manhã, 1984).

Não sendo possível confirmar cabalmente esta hipótese, a sua pertinência decorre do conceito de clareza, um dos valores-notícias elencados por Galtung e Ruge (Galtung \& Ruge, 1965), para quem um acontecimento que suscite muitas dúvidas dificilmente chegará a ser notícia. O mesmo diz Nelson Traquina (2002, p. 198) quando fala em simplificação, lembra que "quanto mais o acontecimento é desprovido de ambiguidade e de complexidade, mais possibilidades tem a notícia de ser notada e compreendida".

Ainda que divulgar as causas da morte de alguém possa interferir com o seu direito de personalidade, não nos parece que o recato ético possa justificar a escassa cobertura da morte de António Variações. Ainda que estejamos perante uma doença diferente e socialmente não estigmatizada, os media não se recataram perante a enfermidade de José Afonso, que sofria de esclerose lateral amiotrófica, tendo sido a sua morte noticiada em todos os jornais. 
Nesta linha de pensamento, outro caso de ruído é o de Vítor Baptista, jogador do Benfica de grande êxito, mas que as circunstâncias da sua vida pessoal votaram ao esquecimento, após ter terminado a sua carreira. A vida do ex-jogador de futebol enquadra-se na tipologia de Chris Rojek (2001, p. 80), para quem o percurso de vida de uma figura pública pode resultar, tanto num processo de flagelação, como na desintegração do seu reconhecimento público (desintegração), como, ainda, na sua recuperação (redenção). No caso de Vítor Baptista, estaríamos perante um caso de flagelação, ou seja, degradação sistemática do seu status de celebridade, quer por motivos internos (auto-degradação), quer por motivos externos à personalidade (exo-degradação) (Rojek, 2001, p. 81). Os casos extremos de flagelação levam à desintegração, o que nos parece ser o caso de Vítor Baptista que se retirou do futebol aos 37 anos, por alegados problemas com drogas, e acabou a exercer a profissão de coveiro, em Setúbal, na miséria. Nestes casos, segundo Chris Rojek, os traços que caraterizavam a celebridade desaparecem por completo e já não podem ser recuperados, pelo que, aquando da sua morte dificilmente esta terá o impacto que teria se ele tivesse falecido antes do processo social e mediático de flagelação. O exemplo de Vítor Baptista espelha bem como uma personalidade pode atingir o seu auge e, face a circunstâncias pessoais, ir decrescendo em relevância até quase cair no esquecimento. Assim, o seu percurso de vida e o afastamento da vida pública representam o ruído que impediu os meios de comunicação social de atribuir à morte de Vítor Baptista o tratamento de uma figura proeminente do mundo do futebol.

\section{Divergências e amplitudes}

Ao longo da nossa análise percebemos que a amplitude da cobertura da morte de cada uma das personalidades não é igual em todos os jornais e que estas divergências, muitas vezes, acontecem com base em critérios pouco claros.

Somando o número de páginas, número de peças e número de imagens publicados a propósito da morte de cada uma das personalidades (Gráfico 7), percebemos quem teve mais e menos destaque, bem como as possíveis divergências no tratamento. Eusébio foi a figura com mais presença mediática no conjunto dos três jornais, seguindo-se Sá Carneiro, Álvaro Cunhal, José Saramago, Salazar e Amália Rodrigues. Os nomes mais consensuais, ou seja, em que a cobertura foi mais equilibrada por parte dos três jornais, são os de Amália Rodrigues, António de Spínola, António Variações, Beatriz Costa, Carlos Paião, Eusébio, Joaquim Agostinho, José Megre, Miguel Torga, Raul Solnado, Sá Carneiro, Sophia de Mello Breyner e Vítor Baptista. 
Gráfico 7. Número total de páginas, peças e imagens, por personalidade, em cada jornal

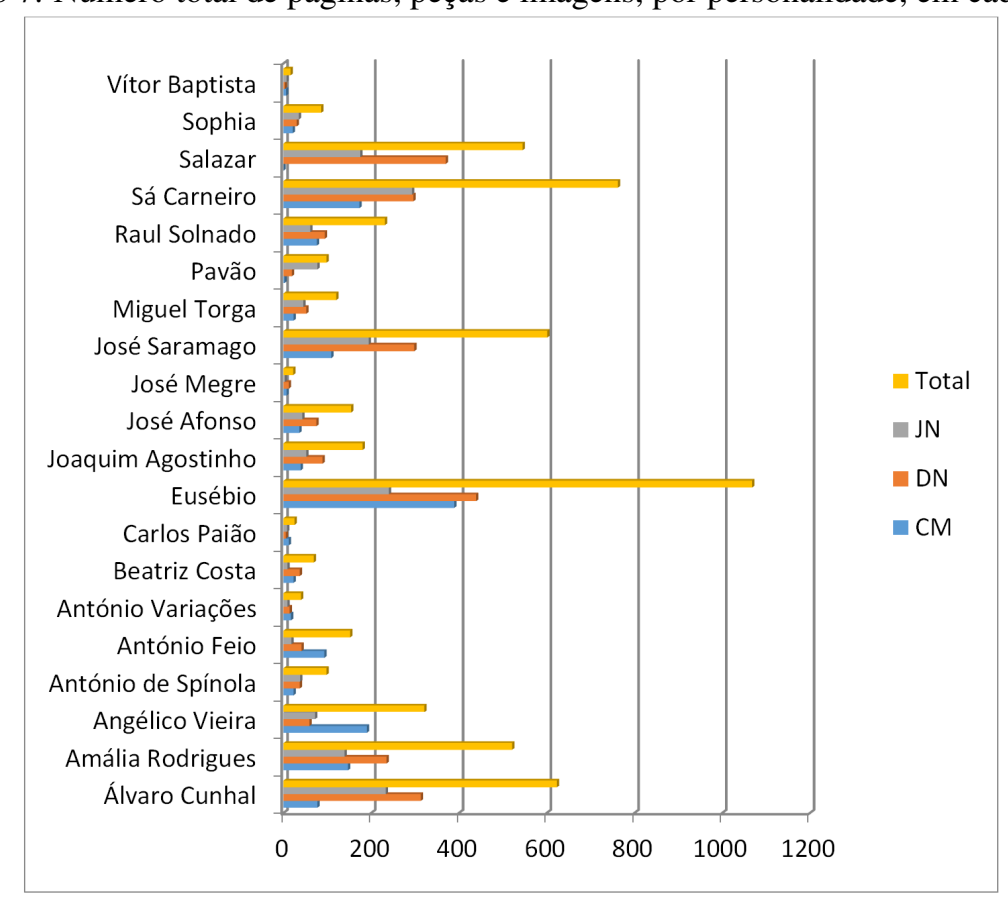

Fonte: Dados recolhidos na pesquisa.

Quanto às discrepâncias encontradas, elas são mais notórias no caso de Álvaro Cunhal, José Saramago, Pavão e Salazar. No caso de José Afonso, esta discrepância verifica-se na cobertura dos onze dias após a sua morte, mas desaparece quando analisamos o total de edições (incluindo as efemérides).

Assim, entre as conclusões a retirar desta análise, está o facto de a amplitude do tratamento noticioso da morte das personalidades poder estar condicionado, no caso das figuras políticas, pela orientação editorial do jornal em causa. No caso de António de Oliveira Salazar ${ }^{2}$ é óbvio que o nível de tratamento foi ditado pelo facto de se tratar da morte do Presidente do Conselho em plena época de vigência do Estado Novo e da censura sobre a imprensa. Assim, a maior amplitude que a morte de Salazar teve no Diário de Notícias explica-se com base na orientação ideológica do título, assim como na menor relevância encontrada no Jornal de Notícias pode ser justificada pelo facto de este periódico ser, desde início dos anos 50 do século XX, um órgão de oposição velada ao regime.

No entanto, há outros casos mais recentes que levantam dúvidas. A morte de Álvaro Cunhal, José Afonso e de José Saramago são disso um exemplo.

2. Nos onze dias após a sua morte, o Diário de Notícias mencionou António de Oliveira Salazar em 16,9\% do total das páginas das suas edições. Esta percentagem foi de 7,8\% no Jornal de Notícias. 
A morte de Álvaro Cunhal, líder histórico do Partido Comunista Português, foi amplamente difundida pelo Diário de Notícias e pelo Jornal de Notícias ${ }^{3}$. Estes dois periódicos também deram muita atenção ao falecimento de José Saramago ${ }^{4}$. Ambos realçaram o facto de ter sido o único Prémio Nobel da Literatura português, bem como referenciaram a sua ação política ligada ao PCP e o seu ateísmo, origem das polémicas públicas em que se viu envolvido. O Diário de Noticias foi o periódico que deu mais atenção a ambos os casos, sendo que, no que toca a José Saramago, não terá sido alheio também o facto de o escritor ter chegado a ser diretor-adjunto daquele periódico. $\mathrm{O}$ mesmo aconteceu no caso de José Afonso, cantautor com música de intervenção e uma conotação política de esquerda, cuja morte mereceu bastante destaque no Diário de Notícias e no Jornal de Notícias, nos onze dias após o seu falecimento ${ }^{5}$.

Ao invés, o Correio da Manhã, na análise dos onze dias que decorreram após a morte, dedicou quase um décimo do espaço ocupado pelo Diário de Notícias à morte de Cunhal, um terço do número de páginas no que concerne ao falecimento de Saramago e um sétimo das páginas ocupadas pelo Diário de Notícias no caso de José Afonso. Apesar de não termos dados objetivos que nos permitam retirar inferências inequívocas, à primeira vista parece-nos que existe algum afastamento em relação a estas três figuras, que têm em comum o seu posicionamento ideológico.

Esse posicionamento está patente na atitude crítica que o Correio da Manhã manteve após o falecimento de José Saramago. No dia após o seu falecimento, o título da pequena chamada na capa do Correio da Manhã diz "Estado paga avião no funeral do escritor" e apenas no seu pós-título explica que: "Nobel faleceu na sua casa nas Canárias, Espanha" (Correio da Manhã, 2010). No interior do jornal, esta visão é acentuada com a divulgação de um inquérito sobre o tema, em que $70 \%$ dos leitores consideram que o Estado não deveria pagar a trasladação do corpo de Saramago. Esta opinião parece legitimar o distanciamento crítico do jornal face a este acontecimento. Esta hipótese não é, porém, inteiramente corroborada pelo editorial do Correio da Manhã, cujo tom elogioso não deixa antever qualquer visão negativa acerca do Nobel da Literatura.

O outro exemplo que contribui para a nossa leitura de que o Correio da Manhã negligencia as figuras associadas à esquerda encontra-se na cobertura da morte de José Afonso. Não só o acontecimento não teve qualquer presença na primeira página do diário no dia seguinte ao cantor morrer, como o Correio da Manhã apenas referenciou José Afonso em duas páginas no total de edições analisadas. Além disso, o conteúdo editorial dá algum relevo à biografia do cantor, mas é caraterizado pela pouca diversidade de vozes (apenas duas personalidades ouvidas). O jornal fez a cobertura do funeral, mas, nos dias que se seguiram, foram anunciadas e tiveram lugar várias homenagens ao cantautor, nenhuma das quais foi noticiada pelo Correio da Manhã. De realçar, no entanto, que este jornal recordou José Afonso aquando dos dez e dos 20 anos após a sua morte, apesar de não o ter feito nas efemérides anteriores, pelo que os dados totais não mostram uma discrepância tão grande de critérios como nos outros casos. No caso da efeméride dos 20 anos, o

3. Nos onze dias após a sua morte, o Diário de Notícias mencionou Álvaro Cunhal em 16,1\% do total das páginas das suas edições. Esta percentagem foi de 7,7\% no Jornal de Notícias e de apenas 2,18\% no Correio da Manhã.

4. Nos onze dias após a sua morte, o Diário de Notícias referenciou José Saramago em 7,82\% do total das páginas das suas edições. Esta percentagem foi de 5,24\% no Jornal de Notícias e de apenas 2,75\% no Correio da Manhã.

5. Nos onze dias após a sua morte, o Diário de Notícias mencionou José Afonso em 2,75\% do total das páginas das suas edições. Esta percentagem foi de 1,32\% no Jornal de Notícias e de apenas 0,29\% no Correio da Manhã. 
jornal chega mesmo a fazer uma chamada na primeira página e aborda o legado musical do artista na voz de alguns músicos e bandas da atualidade. O que nos parece seguro concluir é que José Afonso ganhou autonomia como personalidade nas décadas que se seguiram à sua morte e é hoje aceite como símbolo da cultura portuguesa, pelo que a figura acabou por se impor em relação a qualquer orientação ideológica ou editorial do Correio da Manhã, mais viva na memória pública aquando do seu falecimento. De realçar, aliás, que as duas efemérides são assinaladas no Correio da Manhã, com peças sempre focadas na música e nunca na ideologia nem na participação política de José Afonso.

Quanto a Álvaro Cunhal, além do menor espaço que a sua morte ocupou, face aos outros dois diários, nas edições do Correio da Manhã analisadas, há ainda a destacar questões de foro editorial. À semelhança do que aconteceu no caso de José Saramago, também aqui foi dado destaque a acontecimentos paralelos à própria morte. No dia após o funeral, o Correio da Manhã faz foto de capa com o acontecimento, mas destaca a presença da viúva, da filha e da irmã de Cunhal nas exéquias, enquanto os outros dois periódicos destacam a massa humana de milhares de pessoas que ladearam o caixão no cortejo fúnebre.

Além disso, o Correio da Manhã publica uma entrevista de três perguntas ao historiador António Costa Pinto, cujo título, "Vão ligá-lo ao comunismo e aos seus malefícios" (Pacheco, 2005), nos faz acreditar que há uma opinião latente por parte do jornal em relação a Cunhal. A inserção daquela pequena entrevista parece estar um pouco deslocada do cômputo geral da abordagem jornalística mas, quando colocada lado a lado com o editorial do dia, pode fazer algum sentido. Na sua coluna de opinião, o diretor do jornal, João Marcelino, fala também da morte de Vasco Gonçalves, falecido dois dias antes, e considera que tanto Gonçalves como Cunhal, no rescaldo do 25 de Abril de 1974, "estiveram prestes a lançar Portugal numa guerra civil" (Marcelino, 2005), apresentando o PS e o PSD como verdadeiros partidos democratas. A dada altura o diretor do jornal pergunta: "Álvaro Cunhal morreu sem desfazer o mistério: percebeu, ou não, que devotou a sua vida a uma causa perdida e sem sentido, que se sacrificou por um sistema condenado pela própria natureza humana?" (idem). Analisar esta citação no contexto das três perguntas da entrevista pode fazer algum sentido, uma vez que, na entrevista, o historiador é questionado sobre motivo de a sociedade portuguesa não dar maior expressão política ao PCP. António Costa Pinto responde que, após o 25 de Abril, "os partidos comunistas estavam em queda em termos de estratégia de tomada do poder" e o jornalista questiona se Cunhal teria consciência dessa realidade. O âmbito desta pequena entrevista é, pois, similar ao posicionamento do dirigente do jornal. João Marcelino, no mesmo editorial, refere ainda ser excessiva a atribuição pelo Estado de um dia de luto nacional e acrescenta, em nota de rodapé, que "no campo da cultura, aí sim. Portugal está de luto. Por Manuel Tiago, pseudónimo de Cunhal, é claro que também, mas sobretudo por Eugénio de Andrade, um grande poeta da literatura portuguesa" (Marcelino, 2005). Ora, se o editorial é um texto que denota opinião e que expressa o ponto de vista do meio de comunicação social a respeito das notícias que publica (Albertos, 1974, p. 143), não subsistirão dúvidas de que a posição ideológica do jornal diminuiu a importância pública e política de Álvaro Cunhal.

Ainda de realçar a questão geográfica como determinante da cobertura noticiosa dada a alguns acontecimentos. O Correio da Manhã e o Diário de Notícias têm sede em Lisboa, enquanto o Jornal de Notícias está sediado no Porto. Independentemente disso, os três jornais assumem-se 
como jornais de âmbito nacional, no que toca à cobertura de acontecimentos, apesar de o Jornal de Notícias se assumir como um periódico da região Norte do país. Após a análise dos resultados, ficou claro que essa implantação tem influência no grau de atenção que cada jornal dá ao mesmo acontecimento. A morte súbita de Pavão, jogador do Futebol Clube do Porto, em pleno relvado, durante um jogo de futebol, constitui um acontecimento digno de relato e que, à partida, reuniria todas as condições para que a sua noticiabilidade fosse elevada: inesperado, notoriedade, morte, atualidade, drama, disponibilidade e amplificação. Acontece que o Jornal de Notícias deu bastante mais espaço ao acontecimento do que o Diário de Notícias, dando prioridade ao critério de proximidade, que o ligava ao clube e ao jogador da cidade nortenha . No dia após Pavão ter falecido, o Diário de Notícias faz referência à sua morte no meio do texto da crónica do jogo em questão, apesar de dedicar uma notícia exclusivamente ao acontecimento naquela mesma edição. O maior grau de atenção verificado no Jornal de Noticias não será, portanto, alheio ao facto de Pavão ser jogador do Futebol Clube de Porto, algo patente na extensão da cobertura realizada pelo periódico nortenho, bem como no facto de aquele ter sido o único diário a recordar o jogador aquando dos 20 anos após a sua morte.

\section{Tabloidização}

A morte de cada uma das personalidades analisadas neste estudo assume caraterísticas singulares, ainda que possamos traçar linhas paralelas em algumas delas. A publicação de factos paralelos ou espoletados pela morte da celebridade é uma tendência assumida, sobretudo, pelo Correio da Manhã e pelo Jornal de Notícias. Aquando da morte de Francisco Sá Carneiro, por exemplo, o Correio da Manhã publicou uma breve, falando sobre o facto de um futurólogo ter previsto o assassinato de uma figura política e deixando assim implícita a tese de atentado, logo no dia após a morte do então primeiro-ministro.

A abordagem, por vezes, não se foca na morte em si, mas sim em eventos e acontecimentos paralelos, tal como já aqui referimos a propósito das razões que definem a amplitude da cobertura do tema. Exemplo disto é a notícia da morte de Saramago, dada pelo Correio da Manhã. Na sua capa, o periódico não realça o facto de o escritor ter morrido, mas sim o avião que o Estado fretou para trazer o corpo até Portugal, sendo que no interior do jornal o conteúdo também está bastante ancorado neste facto.

Outro exemplo foi registado após a morte de Angélico Vieira. No dia do seu funeral, o Jornal de Notícias escreveu na primeira página o título "Angélico de branco em urna aberta", destacando que o cantor iria a enterrar com um chapéu, vestido de branco, e sem os seus órgãos, uma vez que estes haviam sido retirados para doação (Jornal de Notícias, 2011). Já no âmbito da morte de António Feio, o Correio da Manhã destaca na sua capa que o ator morreu no dia de anos da filha e que havia perdido 15 quilos com os últimos tratamentos de quimioterapia (Correio da Manhã, 2010). Destaquemos um último exemplo relativo ao Correio da Manhã: quatro dias após

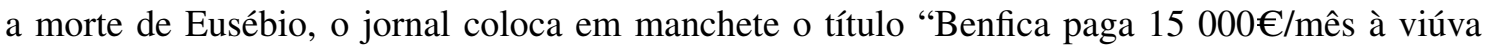
de Eusébio", juntamente com uma pequena imagem de Eusébio deitado no caixão e velado pela mulher (Correio da Manhã, 2014). Segue-se, em pós-título, a informação de que o presidente do Benfica havia garantido as regalias à viúva de Eusébio, que ficaria com o seu salário e com 
uma percentagem das vendas de merchandising. Por sua vez, o Jornal de Notícias fez notícia com o almoço da véspera da morte de Eusébio, um robalo que o antigo jogador de futebol pediu no restaurante Adega da Tia Matilde e não comeu (Farinha, 2014).

Estes casos exemplificam posicionamentos editoriais que colocam os periódicos mais próximos da tabloidização, no sentido da valorização do trivial face a um evento de relevo como é a morte de cada uma destas personalidades, bem como da espetacularização, caraterizada pela diluição da fronteira entre jornalismo e espetáculo, e o predomínio de notícias leves. Aliás, uma das caraterísticas dos jornais populares é a abordagem das questões públicas, a partir de uma perspetiva privada. É por isso que uma das conclusões da nossa análise mostra que existe uma tabloidização, no caso dos Correio da Manhã e do Jornal de Notícias, possivelmente resultado da questão das pressões publicitárias. Os casos de José Saramago, António Feio, Angélico Vieira e Eusébio, falecidos entre 2010 e 2014, ajudam a ilustrar a maior pressão em relação às vendas dos jornais, a crise financeira que assolou os meios de comunicação social nos últimos anos, a tendência para o sensacionalismo que se tornou uma marca da imprensa popular e o processo de acentuação da tabloidização e da espectacularização.

Partindo do conceito da tabloidização como uma estratégia que implica o sacrifício da informação face ao entretenimento e assenta na trivialização, dizer que António Feio morreu no dia de anos da filha e estava 13 quilos mais magro aquando do seu falecimento é uma exploração do voyeurismo, que tem por consequência a trivialização da morte. Esta ideia de trivialização, que põe em causa a seriedade, como lembrava Rowe (2010), e a solenidade da morte, está relacionada com as estratégias comerciais, ajustando os seus conteúdos aos interesses do público. Recordamos que, nos casos acima descritos, falamos de conteúdos que mereceram o destaque das primeiras páginas dos diários.

Por outro lado, os conteúdos que encontrámos nos jornais, e que têm também expressão no interior das edições, confirmam a tese defendida por Patterson (2003) de que hoje predomina uma informação mais leve e menos séria. Recordemos que aquando da morte de António Feio, a cobertura do seu funeral pelo Correio da Manhã incluiu o destaque de temas como as mensagens deixadas no facebook pelos seus entes queridos ou o facto de a sua filha ter conduzido um Porsche para o funeral, devido à paixão que o ator tinha por carros. Aquele diário destacou ainda o número exato de coroas de flores que foram depositadas, a ausência da ex-namorada de António Feio e o facto de a família se ter recusado a prestar declarações à comunicação social.

Tal como dizia Patterson (2003, p. 22), as "notícias que salientam incidentes e assuntos que têm pouco a ver com questões públicas e que são selecionadas pela sua capacidade de chocar, ou de entreter, podem distorcer a percepção que as pessoas têm da realidade”. Esse enviesamento do olhar e enfoque em questões que, numa primeira análise, poderiam parecer irrelevantes acontece também, por exemplo, quando o Correio da Manhã noticia o desmaio da namorada de Angélico Vieira, quando soube da sua morte ou quando o mesmo jornal publica uma página inteira sobre a doação dos órgãos do cantor, que inclui uma entrevista ao diretor da unidade de transplantação do Hospital Curry Cabral. Quando morreu Eusébio, o Correio da Manhã manteve esta estratégia de trivialização e realce de notícias leves, por exemplo, dando conta que o Benfica pagou a conta do funeral do jogador ou fazendo notícia do facto de o atleta benfiquista Cardozo ter mantido sempre uma mão em cima do carro fúnebre onde seguiu Eusébio. 
Lembremo-nos, como confirmam alguns autores, entre os quais Mário Mesquita (2002), Ramonet (1999) e Debord (2002), que os media têm de ser rentáveis e, para isso, precisam de ser lidos, vistos e ouvidos. Uma forma recorrente de chamar a atenção das audiências é, pois, a espetacularização, quer ao nível do predomínio do entretenimento, quer no que toca à atribuição de caraterísticas do espetáculo à informação. Concomitantemente, autores como Ramonet defendem que as imagens televisivas da dor, de sofrimento e de morte causam um impacto nas pessoas que os jornais têm dificuldade em atingir, pelo que a estratégia da imprensa para responder a isto assenta no apelo às emoções do leitor, na inflação dos acontecimentos e na valorização do dramatismo. Tal como confirmámos durante a nossa análise, por exemplo aquando da morte de Angélico Vieira, o Correio da Manhã diferenciou-se no conteúdo, em relação aos outros dois jornais, focando temas emotivos, apelando à sensibilização com textos e imagens sobre o sofrimento dos pais e amigos de Angélico Vieira e destacando pormenores de menor importância, como o facto de, na véspera do acidente, o cantor ter salvado um gato de ser atropelado.

O caso da morte de Angélico Vieira é, aliás, paradigmático no que toca à espetacularização, visto que a grande atenção dada ao acidente que vitimou o cantor denota um olhar mais direcionado para as causas e consequências dramáticas da morte, do que para a personalidade em si.

\section{Discurso de emoção}

Um dos fatores em análise neste estudo foram as marcas de subjetividade do discurso jornalístico, no que toca à cobertura da morte das celebridades. À partida, pensaríamos que o caso de Salazar seria um contraponto do que encontraríamos no pós-25 de Abril. Já esperávamos que a morte do ex-Presidente do Conselho, em pleno Estado Novo, fosse noticiada recorrendo a um texto marcadamente elogioso, quer pela sua importância, quer pelo facto de se viver numa ditadura, quer ainda pelo próprio estilo dos periódicos da época.

Acontece que, mesmo depois da Revolução dos Cravos, que devolveu a liberdade de imprensa aos jornais portugueses, continuámos a registar marcas de subjetividade, nomeadamente a voz do jornalista na notícia e a utilização dos pronomes coletivos, elementos que comunitarizam a dor e o pesar de que o autor da notícia e o próprio jornal dão expressão pública. Também a adjetivação, no sentido do juízo de valor, foi encontrada em elevado grau nas notícias sobre a morte de cada uma das figuras públicas. Parece-nos seguro inferir daqui que o acontecimento morte de uma personalidade pública, pode constituir em si um espaço de exceções às regras da objetividade. Gaye Tuchman (1993) defendia que os jornalistas utilizavam determinadas estratégias, como por exemplo as citações ou a audição dos dois lados do conflito, para mostrar ao mundo que eram objetivos. No caso deste estudo, concluímos que a morte de alguém, enquanto ritual de separação da personalidade do mundo físico, justifica o uso de alguma subjetividade e o jornalista não se coíbe de o mostrar, julgando-se, possivelmente, a coberto de uma exceção presumida ou tolerada. A subjetividade pode ser a expressão da força da figura sobre o discurso mediático, na medida em que é capaz de impor a suspensão crítica do jornal e tolerar o discurso respeitoso e mesmo elogioso, desafiando, assim, as práticas comuns da objetividade e do distanciamento jornalístico exigido noutras circunstâncias. 
Dayan e Katz (2005, p. 22) já haviam identificado esta situação quando se referiram ao tom utilizado pelos jornalistas na descrição e acompanhamento dos acontecimentos cerimoniais. Esta situação pode ser considerada tanto mais estranha quanto os jornalistas são chamados a apresentar os acontecimentos mediáticos com respeito e até com veneração, suspendendo, em nome da criação de consensos, todas as perspetivas críticas, e contrariando o pressuposto da informação jornalística, baseada na ideia do conflito e da crítica (Mesquita, 2003, p. 332). Segundo Dayan e Katz (2005, p. 185), "os jornalistas e as organizações transmissoras tendem a ficar neutralizadas pelo seu papel cerimonial, presos na retórica da lubrificação reverencial”, conceito que também encontramos na descrição de Marc Lits (1993) a propósito do funeral do Rei Balduíno. No âmbito das críticas feitas então aos jornalistas por terem participado no luto, Lits questiona-se se é possível mostrar a emoção sem nos deixarmos contagiar por ela e se é possível mostrar os sentimentos do público sem recorrer a linguagem emocional.

Nós argumentamos que esse poderá ser, precisamente, o caso do discurso jornalístico em torno da morte de uma figura pública. Em alguns dos casos aqui analisados percebemos que o jornalista utiliza algumas expressões mais subjetivas e recorre à utilização de pronomes pessoais, como se ele próprio estivesse inserido no sentimento de pesar e participando no espírito de luto coletivo que rodeia as exéquias da personalidade que acabou de morrer. Segundo Mesquita (2003, p. 332), "o ritual convoca a unanimidade" e na narrativa cerimonial não há lugar para a neutralidade do jornalista.

Entre os exemplos de subjetividade detetados na nossa análise está o tom de uma notícia do Correio da Manhã a propósito da morte de Beatriz Costa: "morreu ontem de manhã (...) e custou a acreditar. Porque Beatriz era daquelas pessoas que fazem de tal forma parte da nossa vida, da nossa memória cultural, que nos convencemos que ao ficar sempre connosco" (Correio da Manhã, 1995). Neste exemplo a subjetividade pode ser identificada, quer pela utilização do pronome pessoal coletivo "nossa", que inclui o jornalista no grupo de pessoas de cujas vidas Beatriz Costa fazia parte, quer pelo facto de o jornal se referir a ela apenas como Beatriz, primeiro nome, sinal de proximidade e intimidade.

Ainda de realçar o caso de Amália Rodrigues, onde se encontram vários exemplos de um tom de pesar partilhado pelo jornalista. Num texto do Correio da Manhã podemos encontrar o uso do pronome pessoal "nós": "apesar de, fisicamente, já não estar entre nós, Amália nunca morrerá. Os seus fados continuarão na voz do povo que ela sempre cantou. Até à eternidade!” (Pereira, 1999). A subjetividade, que se aproxima das crónicas e críticas do jornalismo cultural, está ainda presente em textos onde se leem excertos como "Amália, onde quer que esteja, escute. Está a ouvir? Palmas. Palmas para si. Lágrimas por si. Portugal chorou-a. Portugal cantou-a" (Silva, 1999).

Na análise da morte de Eusébio também detetámos marcas de subjetividade, algumas denotadoras de proximidade, como o facto de o Correio da Manhã ter lançado uma campanha de angariação de fundos para fazer face às despesas da possível trasladação do atleta para o Panteão Nacional. Já no caso do Jornal de Notícias registámos novamente marcas de subjetividade marcadas por uma voz latente de pesar e admiração, em excertos como: "Eusébio não morreu ontem. Passou-se o homem de 71 anos, fica a obra do futebolista, património do Benfica e do futebol, símbolo de uma certa portugalidade ultramarina" (Ferreira, 2014). 
A presença das marcas de subjetividade não pode ser dissociada do discurso da emoção que carateriza as narrativas mediáticas sobre a morte. Segundo Martins (2011, p. 107), trata-se do discurso sensível, comovido e efervescente, um discurso exacerbado emocionalmente, que hoje em dia se opõe ao discurso distante, racional, objetivo e referencial que caraterizava o jornalismo. Marc Lits (2001, p. 8) refere-se à info-emoção como sinónimo de uma estratégia que visa conquistar leitores e/ou espetadores, assente numa lógica de mercado. No entanto, para o autor, a emoção no discurso dos media surge num momento em que a construção da opinião parece ser cada vez menos assumida pelo sistema mediático. Lits (2001, p. 9) exemplifica dizendo que a cobertura mediática da ajuda humanitária em situações de catástrofe extrema substituiu a análise dos problemas de fundo no que toca aos diferentes ritmos de desenvolvimento decorrentes da globalização. O autor sublinha o aumento da emoção nos media, a par de um aumento equivalente no discurso social, uma situação que surge ainda suportada no reconhecimento de que não se trata de um valor negativo do ponto de vista da informação (idem).

Myra MacDonald chama a atenção para o aumento da subjetividade na forma de relatar o acontecimento, uma tendência que tem aumentado as críticas da tabloidização dos media informativos. A autora (MacDonald, 2003, p. 74) centra-se na televisão e considera que os repórteres humanizam a sua posição e sublinham a magnitude dos acontecimentos que estão a cobrir ao demonstrarem que se importam com a ocorrência. O mesmo nos parece acontecer em relação às subjetividades encontradas na cobertura da morte das personalidades. Os exemplos em que é audível um certo tom de pesar atribuído ao jornalista e não às fontes pode ser interpretado como um reforço da negatividade do acontecimento, no sentido em que a morte da personalidade representa uma perda tão grande e inquestionável que até o próprio jornalista tem necessidade de o demonstrar, fazendo da sua subjetividade jornalística a expressão da gravidade do momento vivido.

Ainda assim, o aumento do grau de emoção no discurso dos media não pode ser inferido das conclusões da nossa análise, na medida em que o discurso dominado pela emoção tem os seus exemplos mais claros e mais numerosos na cobertura da morte das personalidades falecidas na primeira metade da nossa linha temporal (entre 1970 e 1996).

Com efeito, as marcas de subjetividade e exemplos de adjetivação diminuíram à medida que os anos foram avançando e eram, nas personalidades que morreram depois de 2000, em muito menor escala. No entanto, voltámos a sentir um recuo no tempo no caso de Eusébio, o que poderíamos atribuir à própria subjetividade admissível, em certas circunstâncias, no jornalismo desportivo, sobretudo no que ao futebol diz respeito, mas que também não podemos desligar da proeminência social da personalidade. De facto, também no caso de Amália Rodrigues, não podemos deixar de notar um registo idêntico, presente na adjetivação utilizada para marcar o caráter ímpar da personalidade.

A reforçar esta ideia, destaque-se o facto de as reportagens e as biografias serem géneros jornalísticos que admitem algum grau de subjetividade. De facto, as marcas de subjetividade aparecem, quase exclusivamente, no decurso das cerimónias fúnebres. As notícias dos dias seguintes são quase sempre marcadas pelo retomar de uma linguagem mais neutra, expressão do distanciamento jornalístico. 


\section{Modificações no jornalismo e opções na cobertura das mortes}

No âmbito deste estudo, pusemos à partida a hipótese de as mudanças na cobertura jornalística da morte da celebridade refletirem as alterações do jornalismo nos últimos 47 anos, algo que confirmámos e podemos inter-relacionar com a prevalência de certos valores-notícia na atualidade e com as mudanças do jornalismo rumo à espetacularização.

No que diz respeito aos valores-notícia, parece-nos claro que a morte, a notoriedade e a novidade são critérios de noticiabilidade transversais a todos os casos aqui analisados. Dependendo da personalidade de que estamos a falar, podemos acrescentar o inesperado (Pavão, Sá Carneiro, Joaquim Agostinho, Carlos Paião, Amália e Angélico Vieira), o potencial de dramatização (Pavão, Sá Carneiro, Joaquim Agostinho, António Variações, Carlos Paião, Vítor Baptista, António Feio, Angélico Vieira e Eusébio), a notabilidade (Sá Carneiro, Carlos Paião, Angélico Vieira), a infração (Angélico Vieira) e a relevância (Salazar, Sá Carneiro, Amália, Álvaro Cunhal, José Saramago e Eusébio). Assim, e face aos valores-notícia elencados por Nelson Traquina (2002), parece-nos que há alguns casos que têm potencialmente associado outros valores-notícia. Porém, a exploração que é feita nem sempre vai ao encontro dessa possibilidade. É o caso da morte de António Variações, cujo potencial de dramatização em torno de uma morte possivelmente causada por uma nova e mortífera doença poderia ter sido aproveitado pelos jornais da época, algo que não aconteceu, como já vimos, devido à ausência de clareza e existência de alguma complexidade com que então se revestia a Sida. O mesmo podemos dizer da morte de Carlos Paião, na sequência de um acidente de viação onde morreu outra pessoa, caso semelhante com o que sucedeu com Angélico Vieira. Este último, foi tratado com acento tónico na dramatização e no sensacionalismo por parte do Correio da Manhã e do Jornal de Notícias, algo que não verificámos no caso de Carlos Paião.

Assim, confirma-se a hipótese que levantámos, acerca da espetacularização da informação, que passa, por exemplo, por um predomínio de notícias mais leves e que correspondem mais facilmente ao interesse do público, opção normalmente atribuída à luta pelas audiências. A chamada de primeira página que o Correio da Manhã faz em torno do avião fretado pelo Estado português para trazer o corpo de José Saramago para Portugal é um exemplo de uma notícia leve, que explora a eventualidade de um caso e que predomina sobre uma abordagem centrada no acontecimento principal: a morte do Prémio Nobel da literatura. A foto de capa em que o Jornal de Notícias refere que Angélico Vieira vai a enterrar de chapéu e sem órgãos corresponde à ideia dos óculos utilizados pelos jornalistas que lhes permitem selecionar, entre todos os factos de um determinado acontecimento, aqueles que são mais sensacionais ou espetaculares, tal como criticava Pierre Bourdieu (1997, p. 25).

A ideia de que os media são, hoje, um campo de espetáculo foi referida por vários autores (Ramonet, 1999) (Mesquita, 2002) (Debord, 2002) (Wolton, 1999) e, tal como defende Vargas Llosa (2013, p. 50), a fronteira entre o jornalismo sério e sensacionalista foi alvo de uma erosão, na medida em que o entretenimento assume, também, um peso cada vez maior na sociedade. Os meios de comunicação social, e neste caso os jornais, foram-se vendo perante a iminência da opção pela informação como instrumento de diversão, realidade que não é imune ao aparecimento da televisão, numa primeira fase, e dos novos media, posteriormente. É por isso que a espetacularização é 
também entendida como uma hipérbole, no sentido do realce exagerado de determinados "casos", em prol do acontecimento central. Esta crítica foi feita por Mário Mesquita (2003), para quem o jornalismo tem optado por inflacionar os acontecimentos e valorizar os temas mais passíveis de gerar dramatismo. Aliás, a ideia de notícia-espetáculo tem eco em alguns dos conteúdos que encontramos nos jornais que analisamos. São disto exemplo a manchete sobre o dinheiro que a viúva de Eusébio iria receber por parte do Benfica, as notícias em torno da rivalidade entre a namorada e ex-namorada de Angélico Vieira aquando da sua morte, os detalhes sobre o cancro que vitimou António Feio ou a notícia de que Angélico tinha salvado um gato de ser atropelado na véspera de morrer. Esta tendência foi algo que identificámos de forma inequívoca no segundo período temporal analisado, com especial enfoque nos casos das mortes ocorridas a partir de 2009. Podemos concluir que se trata de uma mudança efetiva no tratamento noticioso da morte das celebridades, uma vez que esta espetacularização poderia ter sido explorada nos casos de Pavão, Sá Carneiro, Joaquim Agostinho, António Variações e Carlos Paião, mas tal não se verificou.

\section{Conclusão}

O caráter disruptivo da morte manifesta-se nas narrativas mediáticas, em particular, através de duas formas: do inesperado e da notoriedade. Sendo certo que o inesperado é um critério de noticiabilidade a ter em linha de conta, por vezes a morte esperada de uma personalidade de elevada notoriedade já é, por si só, garante de um tratamento mediático mais extenso. Foi a pensar nos diversos contextos de morte e dos próprio media, bem como nas mudanças inerentes ao sector da comunicação social, nos últimos 47 anos, que partimos para este estudo. Quando nos propusemos estudar a morte destas 20 personalidades portuguesas, tínhamos como objetivo analisar as narrativas mediáticas da morte de diferentes figuras públicas e a sua evolução ao longo do tempo. Tínhamos a certeza que a morte era um valor-notícia com bastante peso e estávamos também certos de que a notoriedade poderia alavancar essa noticiabilidade.

Partindo da ideia de que o jornalismo se faz com base no distanciamento e neutralidade, concluímos que no "jornalismo de luto" a morte de uma personalidade de relevância pública é um momento de exceção, um pouco no seguimento da ideia de suspensão crítica referida por Dayan e Katz e já aqui invocada.

A partir desta ideia de luto ritual nos media, não podemos esquecer o que nos dizem autores como Walter (2008, p. 324), para quem os media substituíram as formas religiosas na tentativa de conferir sentido à morte. A construção do luto público acontece a partir dos meios de comunicação social, o que entronca com a noção de comunicação como ritual defendida por James Carey (2009, p. 7), para quem a comunicação, além de uma mera transmissora de informação, é também edificadora de um enquadramento que visa a manutenção da sociedade no tempo. Assim, percebendo os media como produtores de significado, compreendemos que o jornalista desempenha o seu papel de porta-voz da realidade e assume um lugar de destaque na construção da memória coletiva, ainda que a sua motivação não seja a construção histórica, mas sim a atualidade e o imediatismo. Apesar da vocação de atualidade patente na atividade jornalística, o relato dos acontecimentos é muitas vezes balizado pela ideia de passado, no sentido da contextualização, e de futuro, no sentido das possíveis consequências dos acontecimentos. No caso da cobertura das 
mortes das figuras públicas aqui analisada, o ritual de construção do luto público está claramente relacionado com a construção da memória coletiva e, em alguns casos em que se deteta a voz do jornalista, ele próprio se assume como parte integrante desse pesar.

Em termos gerais, dir-se-ia que as mudanças na cobertura jornalística do falecimento morte de personalidades refletem as alterações do jornalismo nos últimos 47 anos. Estas mudanças na cobertura do falecimento de figuras públicas estão diretamente relacionadas com a espetacularização da informação, com o predomínio da chamada informação leve e com a utilização de estratégias de dramatização, que apelam à emotividade e relegam para segundo plano a informação mais distanciada. A pressão das audiências sentida atualmente não será indiferente a esta erosão da fronteira entre jornalismo e entretenimento, com identificação de estratégias do segundo no campo do primeiro. O que o nosso estudo demonstra é que nem sempre a exploração das narrativas se prende com a vertente informativa, tendo ficado demonstrado que alguns factos paralelos e até de foro privado são alvo de exploração mediática. Aliás, uma das tendências que identificámos prende-se com a espetacularização da morte, um caminho que os jornais inauguraram nos últimos anos e que se traduz num tratamento sensacionalista, hiperbólico e dramático, não só da morte, mas também de alguns acontecimentos paralelos a ela associados. As estratégias de espetacularização, apelo à emoção e dramatização são uma tendência que se acentua e é historicamente concomitante com a crise dos media e, em particular, dos jornais.

Esta conclusão vai ao encontro da tipificação de Brin, Charron e Bonville (2004, pp. 3-4), que consideram jornalismo da comunicação como o paradigma vigente, defendendo que face à hiperconcorrência, jornais e jornalistas fazem uso de diferentes estratégias para se manter no mercado. Entre essas estratégias está a subjetividade jornalística, a proliferação dos géneros de crítica e opinião e a integração de comentários e juízos de valor na notícia. Neste jornalismo de comunicação, estamos perante uma mobilização de recursos, por parte dos media, visando criar uma ilusão de comunicação interpessoal com o público (Brin, Charron, \& Bonville, 2004, p. 9). Segundo Charron e Bonville (2004, p. 154), o jornalismo de comunicação tem uma relação diferente com o real, que muitas vezes é relativizado pelos media. Tendo em conta que se trata de um contexto caraterizado pela interatividade da oferta e da procura, o autor considera que os jornalistas podem, por exemplo, escolher o ângulo a partir do qual abordam as ocorrências, colocando o enfoque em questões menos evidentes da realidade, tal como ela é vista pelas pessoas comuns.

Se a presença de elementos tanatológicos na cultura popular de que nos fala Keith Durkin (2003) contribui para neutralizar a morte, na medida em que a torna omnipresente e simultaneamente efémera, não é menos verdade que ela continua a ser um tabu, quer porque a tememos, quer porque ela nos atrai ao mesmo tempo. E essa atração é tanto maior, quanto maior for o grau de notoriedade da personalidade que faleceu. Os jornais procuram responder a esse grau de atenção que as figuras públicas podem suscitar no leitor, o que nos leva a concluir que a tendência nos últimos anos evoluiu de uma morte mais gráfica, em que não há reservas em mostrar o cadáver, para uma morte mais espetacularizada, ainda que o grau de dramatismo e sensacionalismo possa não ser conferido à morte em si, mas sim à exploração mediática de factos secundários. Certo é que os jornais orientaram o seu caminho, nos últimos 47 anos, pela pressão das notícias leves e pela tabloidização e essa tendência também pode ser identificada quando falamos da morte das figuras públicas. 
Tal como considera Madalena Oliveira (2005, p. 1953), os media têm hoje a particularidade de nos fazer olhar a morte dos outros, tornando-nos parte da dor alheia e fazendo-nos mais conscientes da nossa própria morte. A narrativa mediática da morte das figuras públicas encerra em si mesma o próprio rito de passagem de que o homem comum necessita para se consciencializar da morte do outro, num misto de voyeurismo e tabu, equação que conta com o fator do receio da sua própria finitude. Tal como defende esta autora, podemos falar de um "jornalismo de luto" sempre que os meios de comunicação social assumem o papel de construtores do luto e veiculadores de emoções que o público experiencia de forma ficcional. É o caso da cobertura da tragédia da Ponte de Entreos-Rios, em que os jornalistas da estação televisiva SIC usaram roupas de cor preta, tal como já haviam feito no funeral na Princesa Diana (Santos, 2010, p. 96). O mesmo aconteceu em janeiro de 2017 aquando da morte de Mário Soares: alguns jornalistas e comentadores da RTP, da SIC e da TVI envergaram roupa escura para dar a notícia da morte do ex-Presidente da República e para dissertar, em estúdio e em direto, sobre a sua vida e sobre a sua obra. Mas "jornalismo de luto" é também o caso da suspensão crítica em período de luto. As marcas de subjetividade que detetámos nos jornais, utilizadas sobretudo nas biografias e nas reportagens das exéquias, denotam esse tom de pesar, parte da construção do luto e integrante da veiculação de emoções mediadas. Tal como defende Madalena Oliveira (2005, p. 1961), é o prolongamento do sofrimento através dos media de massa, numa aceção próxima à teorização da extensão dos sentidos de Marshall McLuhan.

Madalena Oliveira (2008, pp. 215-216) fala em três níveis de emoção, o primeiro dos quais patente na exploração que os media fazem dos sentimentos dos intervenientes do acontecimento. Segue-se a emoção do próprio jornalista, sempre que abdica da sua objetividade para assumir uma atitude de comprometimento e, o terceiro nível, prende-se com a emoção do público, a partir do momento em que os media suscitam nele um "conjunto de sentimentos gerados pela realidade em si, mas igualmente pelo tipo de relato empreendido pelos jornalistas". Marc Lits (1993, p. 22) diz mesmo que não existe resposta à questão sobre se o jornalista deve participar na emoção que sente, se a deve transmitir ou se se deve manter neutro. Para o autor, naquele momento, a emoção é a informação e ela faz parte do acontecimento a reportar, na medida em que emerge no espaço público, no âmbito de um acontecimento de grande amplitude, como são as exéquias dos chefes de estado. Para o autor o que pode gerar um debate de âmbito deontológico é o grau de participação e de proximidade com essa emoção, por parte do jornalista. De acordo com Madalena Oliveira (2008, p. 222), entre os principais problemas que decorrem do recurso à emoção por parte dos jornalistas está a questão da falta de distância, que aqui identificámos elencando exemplos de marcas de subjetividade, "a confusão entre o que é informação essencial e o que é informação acessória", patente na exploração de factos paralelos também aqui apontados, e a "predisposição para espectacularizar", marca também realçada no tratamento que os jornais fizeram da morte de algumas das figuras públicas deste estudo.

Morte é disrupção e essa disrupção, como qualquer alteração no curso da vida, traz agregados sentimentos, predisposições e distintos discernimentos. Lidamos com cada mudança que atravessa o nosso caminho, ancorados em comportamentos e rituais. Os meios de comunicação social, enquanto parte integrante da sociedade, desempenham um papel de mediação entre cada um de nós e a realidade que nos circunda e assumem, eles próprios, um papel importante de chefe de orquestra no seio desses rituais. Nesse sentido, e encarando a nossa própria morte como um tabu, mas 
encarando a morte dos outros como um misto de negação e fascínio, podemos considerar que a mediatização do desaparecimento de uma personalidade detentora de relevo público contribui para acicatar a nossa curiosidade em torno deste fenómeno, simultaneamente tão distante e omnipresente. A cobertura que os meios de comunicação social fazem da morte das figuras públicas não deixa de ser uma forma ritual de lidar com o acontecimento. Desde logo porque os media aplicam os seus próprios ritos enquanto extensão das emoções do público, e a transição inerente à morte da personalidade é feita por via desses meios de comunicação social. A notícia da morte, a par com o relato biográfico dos feitos daquela personalidade, constitui o primeiro rito de transição, ao qual se segue a cobertura das exéquias, colocando o público no lugar de observador à distância e para quem são selecionados os elementos mais emotivos associados ao acontecimento. Quer as imagens do caixão aberto no primeiro período temporal estudado, quer as estratégias de dramatização patentes no segundo período temporal são exemplos claros de estratégias de aproximação do leitor ao falecido, por via da emoção, tendo o meio de comunicação social como intermediário e observador privilegiado. A questão aqui prende-se com as escolhas editoriais, que podem ir no sentido de dramatizar mais ainda o acontecimento, ou podem ser mais fiéis ao distanciamento crítico que é exigível na cobertura jornalística. A postura de apelo às emoções é condizente com as conclusões retiradas, que apontam para a suspensão crítica e para uma postura subjetiva do jornalista perante a personalidade falecida, sobretudo durante o primeiro período temporal analisado, assumindo-se que a força do momento justifica a utilização da linguagem emotiva. O potencial de dramatização é consonante com a primazia de imagens de dor captadas durante as exéquias e com o olhar intromissivo do jornal perante o caixão aberto. Já a questão da espetacularização é confirmada pela importância dada a questões paralelas à própria morte, como a cremação de um músico sem órgãos, mas com o seu chapéu, ou a quantificação do valor que um clube pagará à viúva de um ex-jogador falecido. Distanciamento, dramatização, emoção ou espetacularização são partes integrantes de um esforço de reconstituição das cerimónias fúnebres, que será tão mais detalhado, quanto maior for o grau de notoriedade da personalidade falecida. É por isso que a transição se fará de forma mais rápida ou mais demorada, com mais ou menos estratégias de captação de atenção do leitor, com ritos mais diferenciados como são também diferenciados os estatutos das personalidades, as suas narrativas de vida e os contextos da sua morte. Ultrapassados os ritos de transição, é tempo de regressar à normalidade, encerrar o período de luto e abrir o espaço de memória, que pode ser reiterado no imediato através da publicação de artigos de opinião recordando o falecido, ou pode surgir apenas aquando das efemérides, estratégia temporal para ancorar a memória da personalidade ou para inserir novos desenvolvimentos e/ou acontecimentos com ela relacionados.

A morte é disruptiva e os meios de comunicação social aproveitam esse momento de interregno para potenciar narrativas biográficas e de dramatização e para se colocarem no papel de mediadores de um certo luto coletivo que acomete ao público. A cobertura da morte das figuras públicas tem sofrido um acréscimo no volume de material informativo produzido, que é tanto maior quanto mais elevado é o grau de notoriedade da personalidade. É o jornalismo da era da hiperconcorrência, o paradigma do jornalismo da comunicação, que está em constante diálogo com o público, que não pode falhar o acontecimento e que se pode permitir certas subjetividades, ao mesmo tempo que se distancia do facto objetivo para se centrar em questões paralelas daquela realidade. Oliveira 
(2008, p. 220) diz mesmo que nos primeiros cinco anos do século XXI os jornalistas se especializaram em explorar momentos da vida privada, no âmbito da morte de figuras públicas, tornando as exéquias e os momentos de pesar, por natureza privados, em "acontecimentos mediáticos de interesse generalizado".

Concomitantemente com a conclusão que aponta no sentido da espetacularização da informação vem o neologismo da pós-verdade, eleita palavra do ano pelos dicionários britânicos Oxford. A ideia subjacente à pós-verdade assenta na primazia da emoção e das opiniões pessoais sobre os factos verificáveis, na formação da opinião pública. No tratamento da morte de algumas figuras públicas, os jornais Correio da Manhã e Jornal de Notícias relegaram, por vezes, para segundo plano os factos em torno da morte das personalidades públicas, dando primazia à emoção e aos factos alternativos passíveis de suscitar polémica. Se a ideia de pós-verdade surgiu por referência aos acontecimentos da dimensão política, parece-nos que o conceito também se pode aplicar ao tratamento que resulta em espectacularização ou info-entretenimento, na medida em que, também nestes casos, a desfocalização do essencial dos acontecimentos a relatar não deixa de ser uma forma de desvalorização dos factos principais face à alternativa dos factos secundários.

\section{Bibliografia}

Albertos, J. L. (1974). Redaccion periodistica: los estilos y los generos en la prensa escrita. Barcelona: A.T.E.

Ariès, P. (2010). Sobre a história da morte no ocidente desde a Idade Média. Lisboa: Editorial Teorema.

Bourdieu, P. (1997). Sobre a televisão. Rio de Janeiro: Jorge Zahar Editor, Lda.

Brin, C.; Charron, J. \& Bonville, J. (2004). Introduction. In B. Collete, J. Charron \& J. Bonville, Nature et transformation du journalisme: théorie et researchs empiriques (pp. 1-33). Laval: Les Presses Universitaires de Laval.

Carey, J. (2009). A cultural approach to communication. Communication \& media studies collection revised edition, 2: 11-28.

Catroga, F. (1999). O céu da memória: cemitério romântico e o culto cívico dos mortos. Coimbra: Minerva.

Charron, J. \& Bonville, J. (2004). Typologie historique des pratiques journalistiques. In B. Collete, J. Charron \& J. Bonville, Nature et transformation du journalisme: théorie et researchs empiriques (pp. 141-217). Laval: Les Presses Universitaires de Laval.

Correio da Manhã. (14 de junho de 1984). António Variações é autopsiado hoje. Correio da Manhã, p. 12.

Correio da Manhã. (16 de abril de 1995). Adeus, meus meninos. Correio da Manhã, p. 34.

Correio da Manhã. (14 de junho de 2005). Álvaro Cunhal 1913-2005. Correio da Manhã, p. 1.

Correio da Manhã. (19 de junho de 2010). Estado paga avião no funeral do escritor. Correio da Manhã, p. 1. 
Correio da Manhã. (31 de julho de 2010). Morte no dia de anos da filha. Correio da Manhã, p. 1. Correio da Manhã. (10 de janeiro de 2014). Benfica paga 15 000€/mês à viúva de Eusébio. Correio da Manhã, p. 1.

Dayan, D. \& Katz, E. (2005). As construções do luto após a morte de Diana. Caleidoscópio: 65-68.

Debord, G. (2002). The society of the spectacle. Canberra: Treason Press.

Diário de Notícias. (14 de agosto de 1996). Morreu o símbolo da transição. Diário de Notícias, p. 1.

Diário de Notícias. (7 de outubro de 1999). Diário de Notícias, p. 1.

Diário de Notícias. (3 de julho de 2004). Sophia 1919-2004. Diário de Notícias, p. 1.

Diário de Notícias. (14 de junho de 2005). Diário de Notícias, p. 1.

Diário de Notícias. (6 de janeiro de 2014). Eusébio 1942-2014. Diário de Notícias, p. 1.

Durkin, K. (2003). Death, dying and the dead in popular culture. In C. Bryant, Handbook of death and dying (pp. 43-49). Londres: Sage Publications.

Elias, N. (1987). La soledad de los moribundos. Mexico: Fondo de Cultura Económica.

Farinha, R. (6 de janeiro de 2014). Eusébio pediu robalo ao almoço mas já não comeu. Jornal de Notícias, p. 7.

Ferreira, A. (6 de janeiro de 2014). Eusébio património do mundo. Jornal de Notícias, p. 2.

Fidalgo, V. (13 de junho de 2004). Variações partiu há 20 anos. Correio da Manhã, p. 69.

Gabler, N. (2001). Toward a new definition of celebrity. Obtido em 26 de Agosto de 2016, de The Norman Lear Center: www.learcenter.org/pdf/Gabler.pdf

Galtung, J. \& Ruge, M. H. (1965). The structure of foreign news. Journal of peace research, 2: 64-91.

Hanusch, F. (2008). Graphic death in the news media: present or absent?. Mortality, 13: 301-317.

Hanusch, F. (2010). Representing death in the news: journalism, media and mortality. Hampshire: Palgrave Macmillan.

Jornal de Notícias. (16 de abril de 1996). Beatriz Costa - Morreu a menina de Lisboa. Jornal de Notícias, p. 1.

Jornal de Notícias. (14 de junho de 2005). Tudo o que faz o Verão subir a prumo chegou ao fim. Jornal de Notícias, p. 1.

Jornal de Notícias. (9 de agosto de 2009). Faz o favor de ser feliz. Jornal de Notícias, p. 1.

Jornal de Notícias. (19 de junho de 2010). A história acabou, não haverá mais nada que contar. Jornal de Notícias, p. 1.

Jornal de Notícias. (30 de junho de 2011). Angélico de branco em urna aberta. Jornal de Notícias, p. 1 . 
Lits, M. (1993). Édition spéciale: le roi est mort. In M. Lits, Le roi est mort. . émotion et médias (pp. 13-24). Bruxelas: Éditions Vie Ouvrière.

Lits, M. (2001). Information, médias et récit médiatique . Belphégor, Littérature Populaire et Culture Médiatique, 1.1.

MacDonald, M. (2003). Exploring media discourse. Nova Iorque: Oxford University Press.

Marcelino, J. (14 de junho de 2005). As mortes de Cunhal e do "companheiro"Vasco. Correio da Manhã, p. 27.

Martins, M. L. (2011). Crise no castelo da cultura: das estrelas para os ecrãs. Coimbra: Grácio Editor.

Mesquita, M. (2002). Informação e espectáculo na luta entre a água e o fogo. Media \& Jornalismo, 1: 113-139.

Mesquita, M. (2003). O quarto equívoco: o poder dos media na sociedade contemporânea. Coimbra: Minerva.

Oliveira, M. (2005). Olhando a morte dos outros. Biblioteca Online de Ciências da Comunicação. Obtido em 27 de outubro de 2016 de: www.bocc.ubi.pt/pag/oliveira-madalena-olhandomorte-outros.pdf

Oliveira, M. (2008). Sensibilidade, mas com bom senso. Tratamento informativo da Dor. In M. Pinto \& S. Marinho, Os media em Portugal nos primeiros cinco anos do século XXI (pp. 213-225). Porto: Campo de Letras.

Pacheco, E. (14 de junho de 2005). Vão ligá-lo ao comunismo e aos seus malefícios. Correio da Manhã, p. 27.

Patterson, T. E. (2003). Tendências do jornalismo contemporâneo: estarão as notícias leves e o jornalismo crítico a enfraquecer a democracia?. Media \& Jornalismo, 2: 19-47.

Pereira, M. (9 de outubro de 1999). Até à eternidade. Correio da Manhã, p. 26.

Ramonet, I. (1999). A tirania da comunicação. Porto: Campo de Letras.

Raposo, L. (25 de agosto de 2014). Como viveu Portugal a morte de Salazar. Diário de Notícias.

Rojek, C. (2001). Celebrity. Londres: Reaktion Books lda.

Rowe, D. (2010). Tabloidization of news. In S. Allan, The routledge companion to news and journalism (pp. 350-361). Oxon: Routledge.

Santos, R. (2010). Do jornalismo aos media. Lisboa: Universidade Católica Editora.

Santos, R. (2011). Fãs e celebridades. Comunicação \& cultura, 12: 11-20.

Schlesinger, P. (1977). Os jornalistas e a sua máquina do tempo. In N. Traquina, Jornalismo: questões, teorias e "estórias" (pp. 177-190). Lisboa: Vega.

Silva, M. A. (9 de outubro de 1999). Muitas vozes e palmas para uma voz insuperável. Diário de Notícias, p. 36. 
Sparks, C. (2000). Introduction: the panic over tabloid news. In C. Sparks \& J. Tulloch, Tabloid tales: global debates over media standards (pp. 1-40). Oxford: Rowman \& Littlefield Publishers.

Traquina, N. (1993). Jornalismo: questões teorias e estórias. Lisboa: Vega.

Traquina, N. (2002). O que é jornalismo. Lisboa: Quimera Editores.

Tuchman, G. (1993). A objectividade como ritual estratégico. In N. Traquina, Jornalismo: questões teorias e estórias (pp. 167-176). Lisboa: Vega.

Vargas Llosa, M. (2013). A civilização do espetáculo. Lisboa: Quetzal.

Walter, T. (2008). The sociology of death. Sociology compass, 2/1: 317-336.

Walter, T. (2015). Communication media and the dead: from the stone age to Facebook. Mortality: promoting the interdisciplinary study of death and dying, 20: 215-232.

Wolton, D. (1999). Pensar a comunicação. Algés: Difel.

Zelizer, B. (2010). About to die - how news images move the public. Nova Iorque: Oxford University Press. 